\title{
Uganda: Second Review Under the Policy Support Instrument and Request for Modification of Assessment Criteria-Staff Report; Staff Supplement; Press Release on the Executive Board Discussion; and Statement by the Executive Director for Uganda
}

In the context of the Second Review Under the Policy Support Instrument for Uganda and its Request for Modification of Assessment Criteria, the following documents have been released and are included in this package:

- $\quad$ the staff report for the Second Review Under the Policy Support Instrument and Request for Modification of Assessment Criteria, prepared by a staff team of the IMF, following discussions that ended on October 5, 2007, with the officials of Uganda on economic developments and policies. Based on information available at the time of these discussions, the staff report was completed on November 29, 2007. The views expressed in the staff report are those of the staff team and do not necessarily reflect the views of the Executive Board of the IMF.

- $\quad$ A staff supplement on the Joint World Bank/IMF debt sustainability analysis.

- $\quad$ a Press Release summarizing the views of the Executive Board as expressed during its December 19, 2007 discussion of the staff report that completed the review.

- $\quad$ a statement by the Executive Director for Uganda.

The documents listed below have been or will be separately released.

Letter of Intent sent to the IMF by the authorities of Uganda*

Memorandum of Economic and Financial Policies by the authorities of Uganda*

*May also be included in Staff Report

The policy of publication of staff reports and other documents allows for the deletion of market-sensitive information.

To assist the IMF in evaluating the publication policy, reader comments are invited and may be sent by e-mail to publicationpolicy@imf.org.

Copies of this report are available to the public from

International Monetary Fund • Publication Services

$70019^{\text {th }}$ Street, N.W. • Washington, D.C. 20431

Telephone: (202) 623-7430 • Telefax: (202) 623-7201

E-mail: publications@imf.org Internet: http://www.imf.org

Price: $\$ 18.00$ a copy

International Monetary Fund

Washington, D.C. 



\title{
INTERNATIONAL MONETARY FUND
}

\section{UGANDA}

\section{Second Review Under the Policy Support Instrument and Request for Modification of Assessment Criteria}

\author{
Prepared by the African Department \\ (In consultation with other departments) \\ Approved by Robert Corker and Mark Plant
}

November 29, 2007

- Main topics. This report recommends completion of the second review under the Policy Support Instrument (PSI). It notes the positive short-term outlook while recognizing prominent challenges ahead. The report also discusses recent developments in the foreign exchange market and in the energy sector.

- $\quad$ PSI. Uganda's second PSI was approved by the Executive Board on December 15, 2006. Program objectives include macro stability, debt sustainability, financial sector deepening and improved public sector financial management.

- $\quad$ Participants. The mission team comprised Messrs. Green (head, AFR), Gershenson, Saenz (both AFR), Tzanninis (PDR), and Jonas (FAD). It visited Kampala on September 25-October 5 and met with Finance Minister Suruma, Bank of Uganda Governor Tumusiime Mutebile, other officials, and representatives of the international community. Mr. Selassie, the Fund's resident representative in Kampala and Mr. Ukpong, senior advisor to Executive Director, participated in the discussions. 


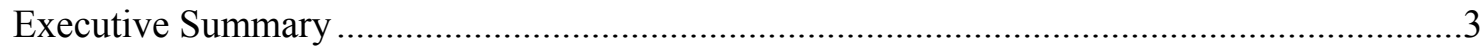

I. Good Performance Amid Concerns About Shilling Appreciation ......................................4

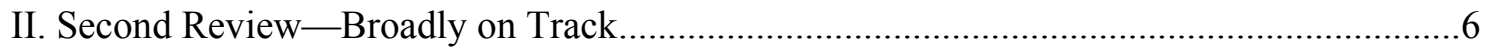

III. Positive Outlook and Prominent Challenges .................................................................6

A. Monetary Management in an Environment of Volatile Foreign Exchange Flows ...6

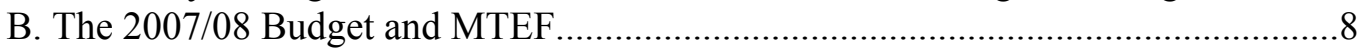

C. Boosting Productivity Through Investment in Infrastructure ................................ 9

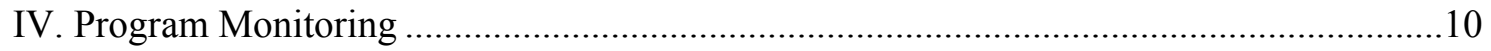

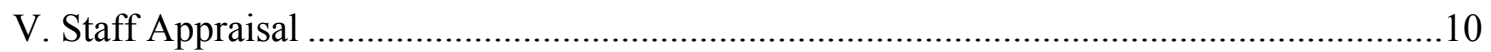

Tables

1. Selected Economic and Financial Indicators, 2005/06-2008/09 ...............................12

2. Fiscal Operations of the Central Government, 2005/06-2009/10 .............................13

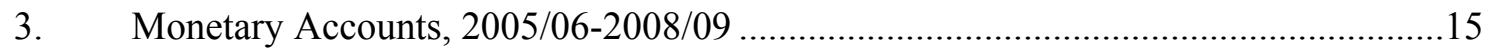

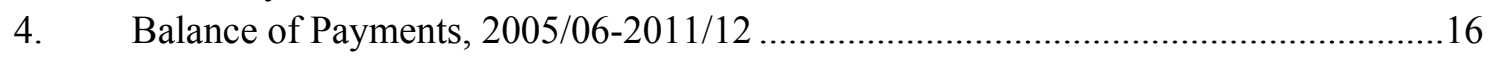

5. Medium-Term Macroeconomic Framework, 2005/06-2009/10 ..............................17

6. Quantitative Assessment Criteria and Indicative Targets for end-June 2007

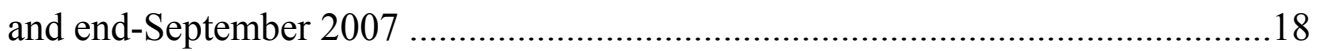

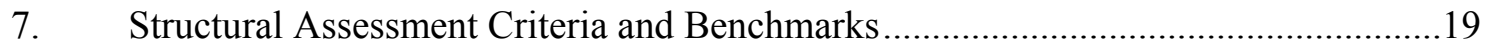

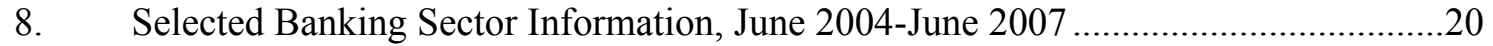

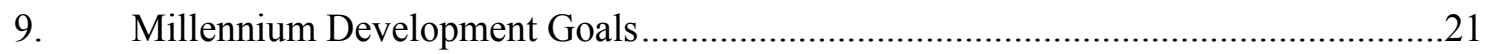

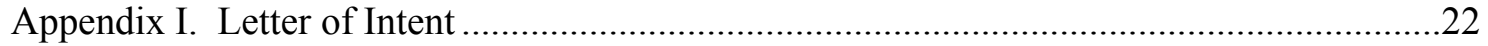

Attachment I. Memorandum of Economic and Financing Policies...........................24

Attachment II. Technical Memorandum of Understanding .......................................31 


\section{Executive Summary}

The staff recommends completion of the second review. All end-June 2007 assessment criteria were met, save the non-observance of the ceiling on increase in base money. Base money returned within the program ceiling during July-September. Macroeconomic performance has been better than expected, and the outlook is positive.

Uganda's medium-term expenditure framework (MTEF) aims at higher public savings based on spending restraint and rising domestic revenue. The 2007/08 budget allows for (i) additional investment in infrastructure, (ii) a near doubling of funds for clearing domestic arrears; and (iii) sufficient expenditure under the Poverty Action Fund (PAF). In line with program objectives, the tax-to-GDP ratio and the overall balance, excluding grants, would both improve.

The Bank of Uganda (BOU) has successfully contained the one-time shocks to prices of increases in electricity tariffs and temporary sugar and diesel fuel shortages. Underlying inflation has come down and is expected to fall below the targeted ceiling of 5 percent by end 2007/08.

Foreign exchange inflows intensified during the first half of 2007. While uncertainty remains, the main causes appear to be strong export performance and interest in shilling assets. The BOU responded appropriately by intervening to limit volatility in Uganda's thin foreign exchange market and allowing base money to exceed the program ceiling temporarily. Looking forward, the BOU is stepping up its timetable for adopting inflation targeting.

Risks to the program appear manageable. High world oil prices and failure to address electricity and infrastructure bottlenecks could dampen buoyant growth prospects. The frontloaded spending profile for 2007/08 leaves little room to deal with additional budgetary pressures that could emerge. Delays to the Bujagali dam would impose substantial costs on the government and business in the medium term. Better and more extensive transport networks and expansion of the pool of long-term savings are also critical for sustainable economic growth. Uganda is assessed to be at low risk of debt distress. 


\section{Good Performance Amid Concerns About Shilling Appreciation}

1. Uganda's impressive economic performance continues. Real GDP growth of 6.5 percent in 2006/07 was supported by strong demand for Ugandan goods from neighboring countries and the year-old ceasefire in northern Uganda. The electricity shortage was alleviated to some extent with the addition of new generating capacity. Inflation, which had been pushed up by temporary factors, is easing as expected.

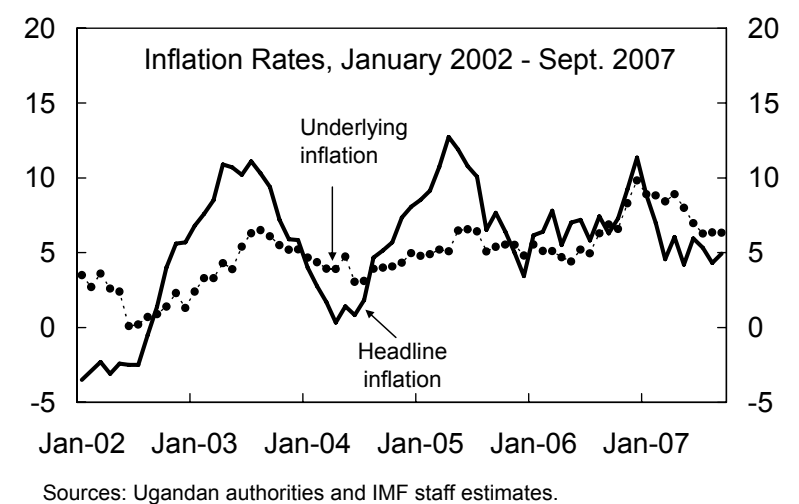

\section{Foreign exchange inflows}

Sources: Ugandan authorities and IMF staff estimates.

intensified over the past year (Box). In consequence, the real effective exchange rate appreciated, although the recent easing of inflation and the stronger euro have mitigated its rise. The loss in this measure of competitiveness, however, did not preclude merchandise exports from growing by 42 percent in 2006/07- the fastest rate in more than a decade - helped by an improvement in the terms of trade.

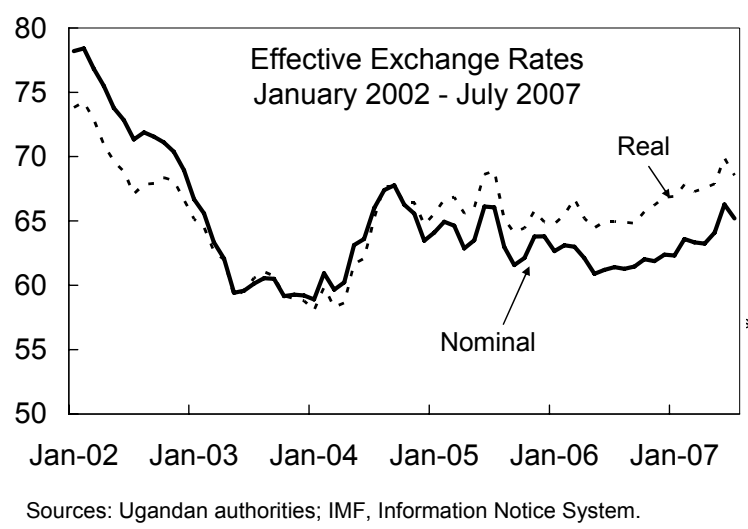

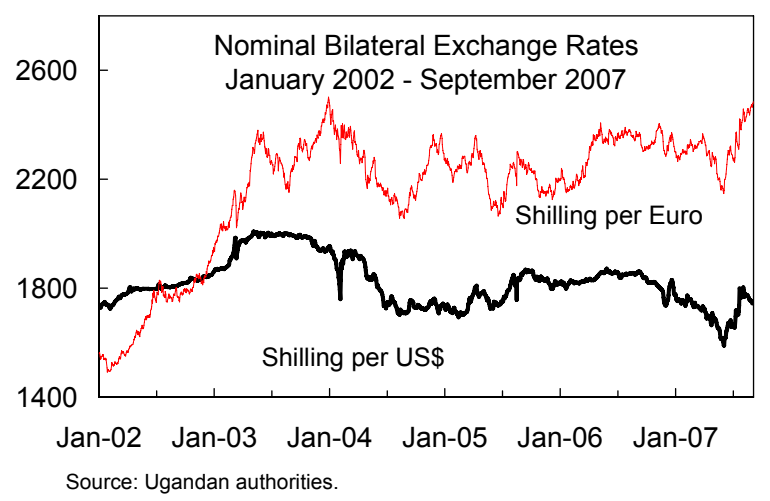




\section{Box. Policy Response to Volatile Foreign Exchange Flows}

Foreign exchange inflows into Uganda intensified in late 2006 leading to sustained appreciation pressure on the shilling. At first the inflows appeared linked to seasonal factors and the IPO of Stanbic, a commercial bank, but subsequently, more sustained influences - export demand for construction goods in neighboring countries, high coffee prices, and improved prospects for oil productionbecame apparent.

A new source of foreign exchange-investment in government securities - emerged in May-June. Faced with strong appreciation pressures and mounting sterilization costs, the BOU halted repo operations and cancelled treasury bill auctions. Short-term interest rates fell sharply, money base expanded, and the appreciation of the shilling was arrested. By end-August, the shilling-dollar exchange rate was back to late-2006 levels.

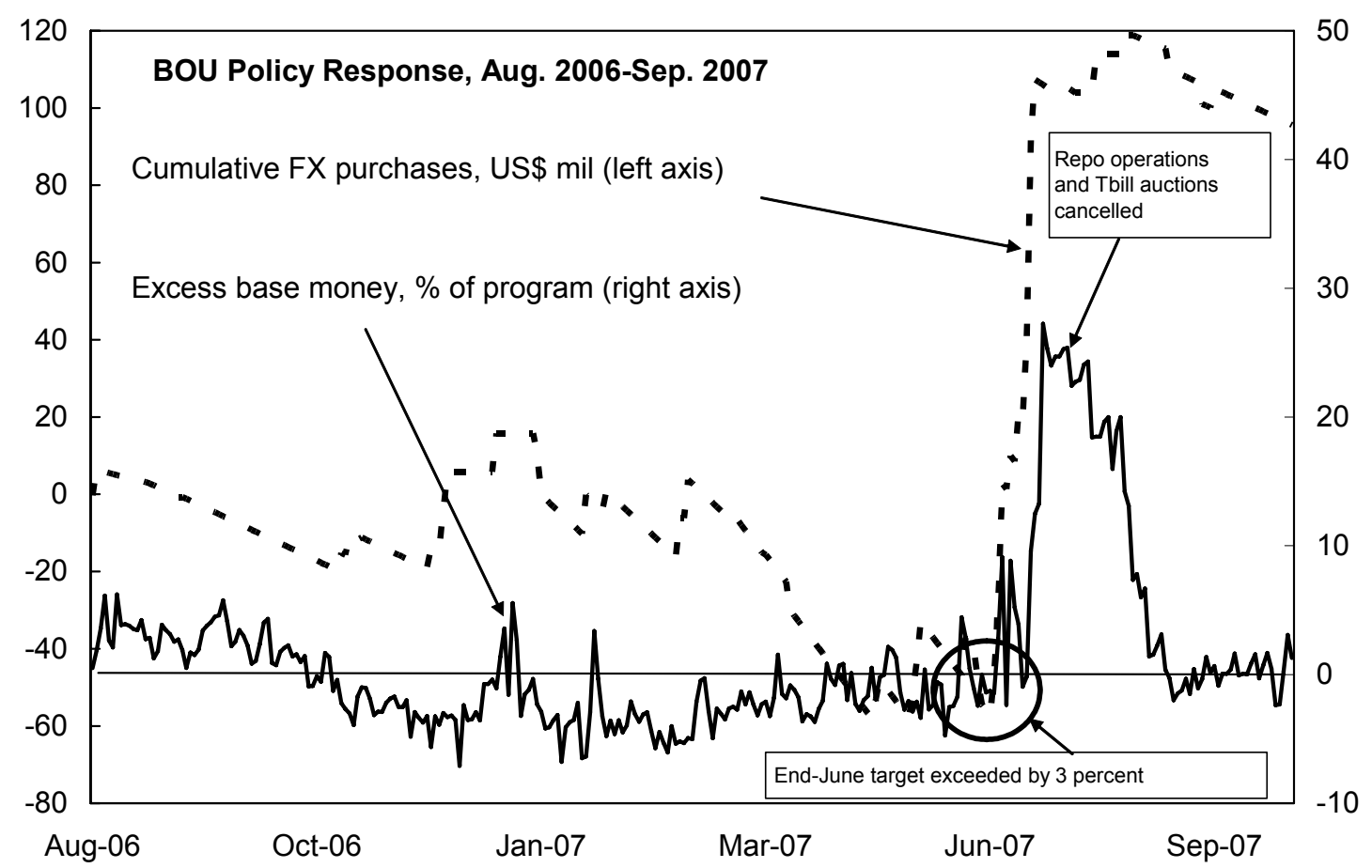

Source: Bank of Uganda 


\section{SECOND REVIEW-BROADLY ON TRACK}

\section{Most program targets were met (Tables 6 and 7).}

- Reflecting the progress with the Uganda Revenue Authority (URA) administration reforms and new tax measures. revenue collection exceeded the initial projections by 0.3 percent of GDP. Accordingly, the end-June assessment criterion on net credit to government was met.

- The BOU allowed base money to exceed its end-June program ceiling in order to alleviate the pressure on the shilling caused by portfolio inflows. By late-August, base money had returned to the target path, and the end-September indicative target was observed.

- Structural measures were implemented as envisaged, including the allocation of more than one percent of GDP to arrears repayment in the 2007/08 budget.

\section{Positive Outlook And Prominent Challenges}

4. Uganda's macroeconomic outlook is positive. Growth projections were revised upward to 7 percent over the next few years reflecting progress in addressing electricity shortages and peace prospects in northern Uganda. ${ }^{1}$ Inflation is projected to return to below five percent by the end of 2007/08, as the impact of earlier shocks dissipates. Imports for Bujagali dam construction will widen the current account deficit but will not undermine external sustainability. The recent surge in oil prices is a downside risk for growth, but the economy has shown resilience in the face of similar shocks in the past.

\section{However, the economy faces the following challenges:}

- $\quad$ Continued strong and volatile foreign exchange flows could complicate the conduct of monetary policy. Policymakers are facing a difficult task of distinguishing between temporary and more permanent flows.

- $\quad$ Further delays in addressing Uganda's road, power, and water infrastructure deficit could undermine medium-term growth.

- $\quad$ The macroeconomic impact of the floods that struck northern and eastern Uganda in September could be significant, but is yet to be estimated.

\section{A. Monetary Management in an Environment of Volatile Foreign Exchange Flows}

\section{In an environment of strong inflows, price stability remains the primary} objective of monetary policy. The BOU will rely primarily on sales of foreign exchange

\footnotetext{
${ }^{1}$ A marked improvement in security situation in northern Uganda followed the 2006 ceasefire. Negotiations on a comprehensive peace settlement are advancing, albeit slowly.
} 
to manage liquidity, as long as this does not destabilize Uganda's shallow foreign exchange market. The BOU, which has ample reserves to deal with potential reversals, will also intervene to reduce volatility and forestall abrupt adjustments but not to counter fundamental pressures (MEFP, paragraphs 9-10).

7. At the same time, rising capital inflows are calling for modifications to the monetary framework. In recent years, Uganda has been able to sustain an independent monetary policy and a relatively stable exchange rate against the backdrop of an open capital account. This status quo, however, is being challenged by strong regional demand for Ugandan goods and foreign investors' budding interest in Ugandan assets - driven in part by prospects for oil production.

\section{Consequently, to allow the BOU additional flexibility and to limit the cost of sterilization, the authorities have adopted the following measures:}

a. Introduce Net Domestic Assets (NDA) of the BOU as the near-term operating target. This would accord the central bank greater flexibility to deal with temporary currency flows or unanticipated shifts in money demand. The fundamental principle of controlling inflation through base money remains unchanged.

b. Allow for a cautious expansion of base money. The appreciated exchange rate, low inflation (save for the impact of well-defined shocks), and the BOU's well-earned credibility suggest that there is scope for faster money growth than previously programmed. Accordingly, the base money target for 2007/08 will (i) incorporate the U Sh 32 billion excess base money observed in June and (ii) allow for a larger decline in velocity than in the past.

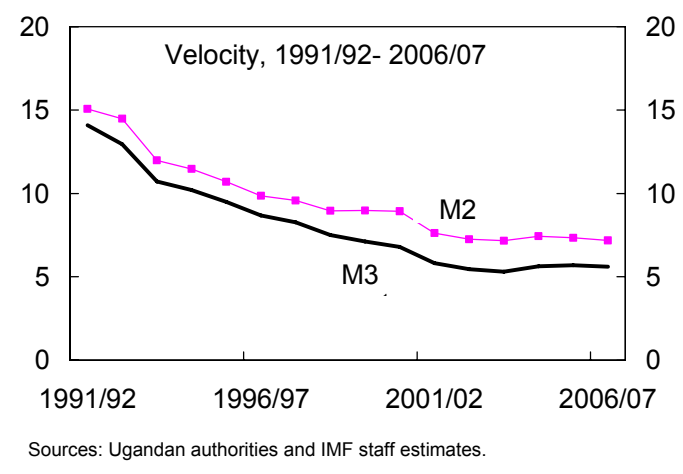

c. $\quad$ Prepare for the eventual adoption of inflation targeting. Research conducted by the BOU suggests that the link between base money and inflation has become tenuous, thereby limiting the effectiveness of base money targeting. To modernize its monetary policy framework, the BOU is in the initial stages of moving to inflation targeting and is working on enhancing the data collection, analysis, and outreach (MEFP, paragraph 12). 
9. A shallow financial sector limits Uganda's ability to absorb foreign exchange inflows and is in itself a formidable obstacle to faster economic growth. Uganda's profitable and well-capitalized banking system - which provides more and more credit to the private sector - is an indication that restructuring of the commercial banks is paying off. Progress in two areas, however, is lagging: (i) access to financial services, both in rural areas (due to infrastructure constraints) and urban areas (due to high cost), and (ii) availability of longerterm credit. The government and the BOU are preparing a comprehensive financial sector development strategy that addresses these

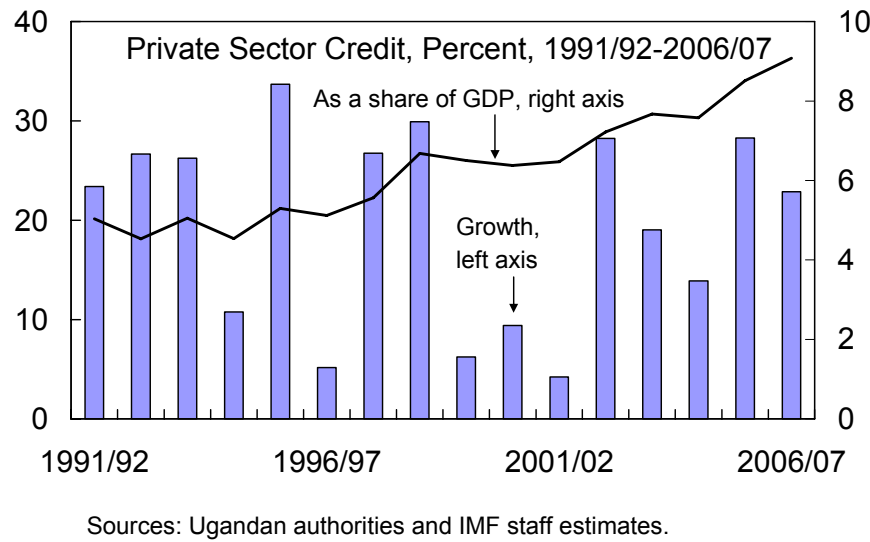
challenges (MEFP, paragraph 11).

\section{B. The 2007/08 Budget and MTEF}

\section{The 2007/08 budget is based on the government's strategy of measured} increases in domestic revenue collection and continued expenditure control. The government is targeting an improvement in domestic revenue by 0.7 percentage point of GDP, to 14.1 percent of GDP, and a reduction in the deficit excluding grants. These targets are feasible, given the better-than-expected tax revenue performance during the last quarter of 2006/07 and the first quarter of 2007/08, tight control over nonpriority spending, and continued efforts to improve tax administration.

\section{Current expenditures will remain broadly constant as a share of GDP.}

Reflecting budget priorities, the government is increasing the allocation to infrastructure investment, energy, education and rural development, as well as arrears repayment. The government is planning to address emerging spending pressures - including those related to Commonwealth Heads of Governments Meeting in November, emergency spending on floods, and peace in the North, totaling about 0.5 percent of GDP - by reallocation within the budget envelope, and if needed, in a supplementary budget bill. To accommodate this pressures without incurring new arrears, the government will need to remain focused on priority spending.

12. The government is increasing efforts to address the long-standing problem of domestic arrears. The steps include rolling out an integrated personnel and payroll system, verification of pension and gratuity arrears for FY 2006/07, and tighter expenditure control through IFMS and prioritization of international commitments. In 
addition, the 2007/08 budget doubles the allocation for clearing old arrears from 0.7 percent to 1.3 percent of GDP (MEFP, paragraph 7 and Table 2).

13. The government has announced investment incentives in the form of tax holidays for exporters. The government indicated that the incentives are in line with the EAC practice and the revenue loss in 2007/08 is expected to be manageable, around 0.1 percent of GDP.

14. Any revenue from oil production-expected to commence in 2009-will be incorporated into the MTEF. The government plans to introduce a national energy policy that aims at transparency, macroeconomic stability, and fiscal sustainability and strikes an appropriate balance between current spending and saving for future needs. (MEFP, paragraph 16).

15. At about one percent of GDP, the domestic interest cost of monetary policy will remain a significant spending item in the near future. As in other countries, it is the responsibility of government to meet the budgetary costs of maintaining price stability. Emphasis on foreign exchange sales in the monetary policy mix will help, as will financial market development in the medium term. More substantial savings will require smaller deficits, achieved by increasing efficiency in the delivery of public services, and by eliminating waste.

\section{Boosting Productivity Through Investment in Infrastructure}

16. Financing arrangements for the Bujagali hydropower project have not been finalized yet, but are expected to be in place before the end of 2007. Constructionexpected to last three years - has started with the use of a US\$75 million bridge loan, provided by the government. The loan is expected to be repaid when the full financing package is in place.

17. To speed up its investment in infrastructure, the government is considering turnkey projects (MEFP, paragraph 15). Compared with the donor-financed projects, turnkey projects - while possibly financed on nonconcessional terms - could be implemented faster, resulting in substantial savings to the economy as a whole. Uganda's

pressing infrastructure needs, well-known difficulties in implementing the donor-financed projects, and the existing room to borrow-as demonstrated by the joint World BankFund DSA — render turnkey projects a viable avenue for investment. However, all projects need to be evaluated on a case-by-case basis to demonstrate cost-effectiveness and assess the impact on debt sustainability.

\section{The government's new Debt Strategy will govern project selection and}

financing. To ensure debt sustainability, the strategy - to be finalized by the end of 2007-lays out a comprehensive approach to debt contracting and management. It will allow borrowing only for priority sectors (water, electricity, roads) on concessional terms, although some priority projects could have a grant element less favorable than IDA. 


\section{Program Monitoring}

19. For monitoring performance under the program, quantitative assessment criteria, quantitative indicative targets, and structural assessment criteria and benchmarks have been set (MEFP, Tables 1 and 2):

a. Starting with the end-December 2007 test date, the quantitative assessment criterion on base money will be replaced by an assessment criterion on NDA of the BOU, and the ceiling on base money will become an indicative target. The end-December 2007 assessment criterion on net claims on government was modified to reflect the intrayear spending reallocation-reflecting the pressures outlined in paragraph 11 and the later-than-expected repayment of the Bujagali bridge loan - in the approved 2007/08 budget.

b. Owing to the delay in finalizing the financing for Bujagali, the repayment of the bridge loan has been reprogrammed from end-December 2007 to end-June 2008. In consequence, quarterly, but not end-year, targets for net international reserves and net credit to government changed.

c. The implementation date for the structural assessment criterion on submitting to cabinet a policy paper on new regulatory framework for nonbank financial institutions has been changed from end-January to endJune 2008 to allow time for its thorough preparation. Former benchmarks on roll-out of the Integrated Personnel and Payroll System and on introduction of national identity card system have been modified and made assessment criteria (Table 7).

d. An additional structural assessment criterion-on allocating U Sh 300 billion for arrears repayment in 2008/09 - and three new benchmarks were added. The benchmarks aim at facilitating the expansion of the financial sector, strengthening the PFM, and ensuring prudent use of oil reserves.

\section{Staff Appraisal}

20. The staff recommends completion of the second review. Competent macroeconomic management and an appropriate response to the acute electricity crisis have facilitated a better-than-expected economic performance. All assessment criteria, save the ceiling on base money, were observed. Staff supports the authorities' request for a waiver of this missed assessment criterion, because the deviation was temporary and the end-September indicative base money target was observed.

21. A prudent approach to public finances is at the heart of Uganda's past success and current economic program. The authorities appropriately aim for increased public sector savings in the medium term to promote private sector development and to minimize the costs of sterilization.

22. Uganda's well-known infrastructure deficit must be addressed to ensure favorable growth prospects for the medium term. The joint World Bank-Fund DSA 
shows that the risk of debt distress remains low and that there is room to borrow. For macrocritical infrastructure, turnkey projects could be considered on a case-by-case basis and subject to careful cost-benefit analysis, implementation safeguards, and transparent accounting.

23. The authorities are to be commended for their commitment to price stability. BOU intervention during June-July was instrumental in reducing the pressure on Uganda's shallow foreign exchange market and, therefore, appropriate. Looking forward, changes to the monetary framework should help Uganda deal with short-term foreign exchange inflows. In the event that foreign exchange inflows persist, however, longerterm economic prospects will depend on making Uganda's businesses more productive by alleviating key infrastructure bottlenecks and by encouraging further development of the financial sector. The authorities' intention to design a strategy for further development of the financial sector is welcome.

24. Staff welcomes the government's thorough deliberations to make the best use of Uganda's oil resources. It will be important to ensure that oil is used prudently and transparently and that the macroeconomic impact of oil is taken into account.

25. Short-term risks to the program appear manageable. High oil prices could slow economic growth and add to budgetary pressures. An overshoot of CHOGM-related expenditure may jeopardize priority spending. In general, the spending profile for $2007 / 08$ is heavily frontloaded to account for CHOGM and several other one-off items, leaving little room to deal with additional budgetary pressures that can emerge towards the end of the year. The government will need to remain focused on priority spending to limit new arrears.

\section{The main medium-term risk would be failure to enhance Uganda's} infrastructure and electricity-generating capacity. As the economy expands, the inadequate road network - already stretched to the limit — will be a brake for growth. Further delays in construction of the Bujagali dam and in planning for additional capacity would impose substantial costs on the public and private sectors. 
Table 1. Uganda: Selected Economic and Financial Indicators, 2005/06-2008/09 ${ }^{1}$

\begin{tabular}{|c|c|c|c|c|c|}
\hline & \multirow{2}{*}{$\begin{array}{r}2005 / 06 \\
\text { Act. }\end{array}$} & \multicolumn{2}{|c|}{$2006 / 07$} & \multirow{2}{*}{$\begin{array}{r}2007 / 08 \\
\text { Proj. } \\
\end{array}$} & \multirow{2}{*}{$\begin{array}{r}2008 / 09 \\
\text { Proj. }\end{array}$} \\
\hline & & Prog. & Est. & & \\
\hline \multicolumn{6}{|l|}{ GDP and prices (percent change) } \\
\hline Real GDP & 5.1 & 6.2 & 6.5 & 7.1 & 7.0 \\
\hline Headline inflation (average) & 6.6 & 7.5 & 6.8 & 4.5 & 5.0 \\
\hline Underlying inflation (average) & 5.2 & 8.1 & 7.8 & 4.8 & 4.0 \\
\hline \multicolumn{6}{|l|}{ External sector (percent change) } \\
\hline Terms of trade (deterioration-) & 16.5 & 11.7 & 6.8 & -4.0 & -3.2 \\
\hline Real effective exchange rate (depreciation-) & -1.0 & ... & 2.0 & $\ldots$ & .. \\
\hline \multicolumn{6}{|l|}{ Money and credit (percent change) } \\
\hline Broad money (M2) & 18.9 & 15.3 & 16.7 & 16.6 & 14.8 \\
\hline Domestic credit & 7.2 & 3.3 & -6.4 & 14.3 & 15.3 \\
\hline Credit to the central government ${ }^{2}$ & -4.8 & -7.2 & -17.2 & 0.8 & -0.4 \\
\hline Private sector credit & 28.3 & 22.2 & 22.9 & 28.7 & 30.3 \\
\hline \multicolumn{6}{|l|}{ Savings and investment (percent of GDP) } \\
\hline Domestic investment & 23.4 & 24.2 & 24.5 & 27.6 & 28.4 \\
\hline Public & 4.9 & 5.1 & 5.4 & 7.0 & 7.8 \\
\hline Private & 18.5 & 19.2 & 19.1 & 20.6 & 20.6 \\
\hline National savings (excluding grants) & 13.8 & 15.7 & 15.9 & 15.0 & 14.7 \\
\hline Public & -2.4 & -3.4 & -1.5 & -0.8 & 0.0 \\
\hline Private & 16.3 & 19.1 & 17.3 & 15.7 & 14.7 \\
\hline \multicolumn{6}{|l|}{ External sector (percent of GDP) } \\
\hline Current account balance (including grants) & -4.0 & -2.5 & -2.0 & -8.0 & -9.5 \\
\hline Net donor inflows & 8.1 & 8.6 & 10.0 & 8.1 & 8.0 \\
\hline Current account balance (excluding grants) & -9.5 & -8.6 & -8.6 & -12.6 & -13.7 \\
\hline External debt (including Fund) & 43.0 & 13.6 & 11.7 & 15.9 & 19.5 \\
\hline External debt-service ratio ${ }^{3,4}$ & 5.7 & 3.3 & 4.9 & 5.0 & 3.5 \\
\hline \multicolumn{6}{|l|}{ Government budget and debt (percent of GDP) } \\
\hline Revenue & 13.1 & 13.1 & 13.4 & 14.1 & 14.6 \\
\hline Grants & 6.5 & 5.9 & 6.3 & 4.3 & 3.9 \\
\hline Total expenditure and net lending & -20.4 & -21.5 & -21.9 & -21.8 & -22.8 \\
\hline Overall balance (including grants) & -0.8 & -2.5 & -2.3 & -3.4 & -4.2 \\
\hline Overall balance (excluding grants) & -7.3 & -8.4 & -8.6 & -7.7 & -8.2 \\
\hline Stock of domestic debt & 9.1 & 7.2 & 9.9 & 9.9 & 7.9 \\
\hline \multicolumn{6}{|l|}{ Memorandum items: } \\
\hline Nominal GDP (U Sh billions) & 17,330 & 19,934 & 19,962 & 22,223 & 24,880 \\
\hline Average exchange rate (U Sh per US\$) & 1,825 & $\ldots$ & 1,778 & $\ldots$ & $\ldots$ \\
\hline Treasury bill yield (percent) & 7.8 & $\ldots$ & 9.4 & $\ldots$ & ... \\
\hline Overall balance of payments (US $\$$ millions) & 254 & 172 & 719 & 86 & 41 \\
\hline \multicolumn{6}{|l|}{ Gross foreign exchange reserves } \\
\hline (months of next year's imports of goods and services) & 4.7 & 4.7 & 5.8 & 5.2 & 4.8 \\
\hline
\end{tabular}

Sources: Ugandan authorities; and IMF staff estimates and projections.

1 Fiscal year begins in July.

2 Percent of M3 at start of the period.

${ }^{3}$ Percent of exports of goods and nonfactor services.

${ }^{4}$ Including Fund obligations; reflects actual debt service paid, including debt relief. 
Table 2. Uganda: Fiscal Operations of the Central Government, 2005/06-2009/10 ${ }^{1}$

\begin{tabular}{|c|c|c|c|c|c|c|}
\hline & \multirow{2}{*}{$\begin{array}{r}\text { 2005/06 } \\
\text { Actual }\end{array}$} & \multicolumn{2}{|c|}{$2006 / 07$} & \multirow{2}{*}{$\begin{array}{r}\text { 2007/08 } \\
\text { Proj. }\end{array}$} & \multirow{2}{*}{$\begin{array}{r}\text { 2008/09 } \\
\text { Proj. }\end{array}$} & \multirow{2}{*}{$\begin{array}{r}2009 / 10 \\
\text { Proj. }\end{array}$} \\
\hline & & Prog. & Actual & & & \\
\hline & \multicolumn{3}{|c|}{ (U Sh billions) } & & & \\
\hline Total revenue and grants & 3,395 & 3,776 & 3,917 & 4,085 & 4,615 & 5,130 \\
\hline Revenue & 2,267 & 2,602 & 2,667 & 3,135 & 3,635 & 4,184 \\
\hline Tax & 2,142 & 2,457 & 2,524 & 2,965 & 3,446 & 3,975 \\
\hline International trade taxes & 227 & 259 & 261 & 297 & 355 & 404 \\
\hline Income taxes & 653 & 750 & 782 & 924 & 1,091 & 1,282 \\
\hline Excises & 567 & 704 & 653 & 802 & 865 & 991 \\
\hline Value-added tax & 696 & 745 & 829 & 931 & 1,141 & 1,362 \\
\hline Additional revenue effort & 0 & -5 & 0 & 12 & -6 & -64 \\
\hline Nontax & 125 & 150 & 144 & 170 & 190 & 210 \\
\hline Grants & 1,129 & 1,174 & 1,249 & 949 & 980 & 945 \\
\hline Budget support & 715 & 722 & 723 & 481 & 481 & 438 \\
\hline Of which: MDRI (IMF) & 232 & & & & & \\
\hline Project grants & 413 & 452 & 526 & 468 & 499 & 507 \\
\hline Expenditures and net lending & 3,532 & 4,283 & 4,376 & 4,842 & 5,668 & 6,160 \\
\hline Current expenditures & 2,233 & 2,392 & 2,442 & 2,733 & 2,733 & 3,083 \\
\hline Wages and salaries & 867 & 976 & 987 & 1,112 & 1,136 & 1,304 \\
\hline Interest payments & 249 & 256 & 236 & 297 & 305 & 286 \\
\hline Other current & 1,117 & 1,160 & 1,220 & 1,324 & 1,292 & 1,594 \\
\hline Development expenditures & 1,238 & 1,617 & 1,682 & 1,875 & 2,445 & 2,586 \\
\hline Donor-supported projects & 720 & 885 & 968 & 1,170 & 1,468 & 1,491 \\
\hline Domestic-financed & 519 & 732 & 714 & 704 & 977 & 1,094 \\
\hline Of which: add'I energy crisis spending & $\ldots$ & 207 & 207 & 92 & 160 & 160 \\
\hline Net lending and investment & -29 & 57 & 101 & -165 & -40 & -39 \\
\hline Other spending ${ }^{2}$ & 91 & 217 & 151 & 400 & 530 & 530 \\
\hline \multicolumn{7}{|l|}{ Overall balance } \\
\hline Including grants & -137 & -507 & -459 & -757 & $-1,053$ & $-1,030$ \\
\hline Excluding grants & $-1,265$ & $-1,681$ & $-1,708$ & $-1,707$ & $-2,032$ & $-1,975$ \\
\hline Excl. grants and add'I energy spending & & $-1,474$ & $-1,501$ & $-1,615$ & $-1,872$ & $-1,815$ \\
\hline Financing & 63 & 507 & 413 & 757 & 1,053 & 1,030 \\
\hline External financing (net) & 267 & 671 & 617 & 696 & 973 & 1,013 \\
\hline Disbursement & 466 & 828 & 829 & 893 & 1,157 & 1,175 \\
\hline Budget support & 76 & 395 & 249 & 191 & 188 & 191 \\
\hline Project loans & 390 & 433 & 580 & 702 & 969 & 984 \\
\hline Amortization (-) & -149 & -111 & -165 & -132 & -142 & -136 \\
\hline Exceptional financing & -50 & -45 & -47 & -66 & -44 & -29 \\
\hline Domestic financing (net) & -204 & -164 & -205 & 62 & 79 & 17 \\
\hline Bank financing & -135 & -235 & -562 & 31 & -19 & 17 \\
\hline Of which: MDRI-related government deposits & & 56 & 56 & 44 & 55 & 34 \\
\hline Nonbank financing & -69 & 71 & 357 & 31 & 98 & 0 \\
\hline Errors and omissions/financing gap & 74 & 0 & 46 & 0 & 0 & 0 \\
\hline \multicolumn{7}{|l|}{ Memorandum items: } \\
\hline MDRI spending & $\ldots$ & 56 & 56 & 44 & 55 & 34 \\
\hline MDRI debt relief from IDA & $\ldots$ & 4,560 & 4,541 & $\ldots$ & $\ldots$ & $\ldots$ \\
\hline MDRI debt relief from the AfDF & $\ldots$ & 938 & 934 & $\ldots$ & $\ldots$ & $\ldots$ \\
\hline
\end{tabular}


Table 2. Uganda: Fiscal Operations of the Central Government, 2005/06-2009/10 (concluded)

\begin{tabular}{|c|c|c|c|c|c|c|}
\hline & \multirow{2}{*}{$\begin{array}{r}\text { 2005/06 } \\
\text { Actual } \\
\end{array}$} & \multicolumn{2}{|c|}{$2006 / 07$} & \multirow{2}{*}{$\begin{array}{r}\text { 2007/08 } \\
\text { Proj. } \\
\end{array}$} & \multirow{2}{*}{$\begin{array}{r}\text { 2008/09 } \\
\text { Proj. } \\
\end{array}$} & \multirow{2}{*}{$\begin{array}{r}2009 / 10 \\
\text { Proj }\end{array}$} \\
\hline & & Prog. & Actual & & & \\
\hline & \multicolumn{3}{|c|}{ (Percent of GDP) } & & & \\
\hline Total revenue and grants & 19.6 & 18.9 & 19.6 & 18.4 & 18.5 & 18.5 \\
\hline Revenue & 13.1 & 13.1 & 13.4 & 14.1 & 14.6 & 15.1 \\
\hline Tax & 12.4 & 12.3 & 12.6 & 13.3 & 13.8 & 14.4 \\
\hline International trade taxes & 1.3 & 1.3 & 1.3 & 1.3 & 1.4 & 1.5 \\
\hline Income taxes & 3.8 & 3.8 & 3.9 & 4.2 & 4.4 & 4.6 \\
\hline Excises & 3.3 & 3.5 & 3.3 & 3.6 & 3.5 & 3.6 \\
\hline Value-added tax & 4.0 & 3.7 & 4.2 & 4.2 & 4.6 & 4.9 \\
\hline Additional revenue effort & 0.0 & 0.0 & 0.0 & 0.1 & 0.0 & -0.2 \\
\hline Nontax & 0.7 & 0.8 & 0.7 & 0.8 & 0.8 & 0.8 \\
\hline Grants & 6.5 & 5.9 & 6.3 & 4.3 & 3.9 & 3.4 \\
\hline Budget support & 4.1 & 3.6 & 3.6 & 2.2 & 1.9 & 1.6 \\
\hline Of which: MDRI (IMF) & 1.3 & & $\ldots$ & . & & \\
\hline Project grants & 2.4 & 2.3 & 2.6 & 2.1 & 2.0 & 1.8 \\
\hline Expenditures and net lending & 20.4 & 21.5 & 21.9 & 21.8 & 22.8 & 22.2 \\
\hline Current expenditures & 12.9 & 12.0 & 12.2 & 12.3 & 11.0 & 11.1 \\
\hline Wages and salaries & 5.0 & 4.9 & 4.9 & 5.0 & 4.6 & 4.7 \\
\hline Interest payments & 1.4 & 1.3 & 1.2 & 1.3 & 1.2 & 1.0 \\
\hline Other current & 6.4 & 5.8 & 6.1 & 6.0 & 5.2 & 5.8 \\
\hline Development expenditures & 7.1 & 8.1 & 8.4 & 8.4 & 9.8 & 9.3 \\
\hline Donor-supported projects & 4.2 & 4.4 & 4.8 & 5.3 & 5.9 & 5.4 \\
\hline Domestic-financed & 3.0 & 3.7 & 3.6 & 3.2 & 3.9 & 4.0 \\
\hline Of which: add'I energy crisis spending & $\ldots$ & 1.0 & 1.0 & 0.4 & 0.6 & 0.6 \\
\hline Net lending and investment & -0.2 & 0.3 & 0.5 & -0.7 & -0.2 & -0.1 \\
\hline Other spending $^{2}$ & 0.5 & 1.1 & 0.8 & 1.8 & 2.1 & 1.9 \\
\hline \multicolumn{7}{|l|}{ Overall balance } \\
\hline Including grants & -0.8 & -2.5 & -2.3 & -3.4 & -4.2 & -3.7 \\
\hline Excluding grants & -7.3 & -8.4 & -8.6 & -7.7 & -8.2 & -7.1 \\
\hline Excl. grants and add'I energy spending & $\ldots$ & -7.4 & -7.5 & -7.3 & -7.5 & -6.6 \\
\hline Financing & 0.4 & 2.5 & 2.1 & 3.4 & 4.2 & 3.7 \\
\hline External financing (net) & 1.5 & 3.4 & 3.1 & 3.1 & 3.9 & 3.7 \\
\hline Disbursement & 2.7 & 4.2 & 4.2 & 4.0 & 4.6 & 4.2 \\
\hline Budget support & 0.4 & 2.0 & 1.2 & 0.9 & 0.8 & 0.7 \\
\hline Project loans & 2.2 & 2.2 & 2.9 & 3.2 & 3.9 & 3.6 \\
\hline Amortization (-) & -0.9 & -0.6 & -0.8 & -0.6 & -0.6 & -0.5 \\
\hline Exceptional financing & -0.3 & -0.2 & -0.2 & -0.3 & -0.2 & -0.1 \\
\hline Domestic financing (net) & -1.2 & -0.8 & -1.0 & 0.3 & 0.3 & 0.1 \\
\hline Bank financing & -0.8 & -1.2 & -2.8 & 0.1 & -0.1 & 0.1 \\
\hline Nonbank financing & -0.4 & 0.4 & 1.8 & 0.1 & 0.4 & 0.0 \\
\hline Errors and omissions/financing gap & 0.4 & 0.0 & 0.2 & 0.0 & 0.0 & 0.0 \\
\hline \multicolumn{7}{|l|}{ Memorandum item: } \\
\hline MDRI spending & $\ldots$ & 0.3 & 0.3 & 0.2 & 0.2 & $\cdots$ \\
\hline MDRI debt relief from IDA & $\ldots$ & 22.9 & 22.8 & $\ldots$ & $\ldots$ & $\cdots$ \\
\hline MDRI debt relief from the AfDF & $\ldots$ & 4.7 & 4.7 & $\ldots$ & $\ldots$ & $\cdots$ \\
\hline
\end{tabular}

Sources: Ugandan authorities; and Fund staff estimates and projections.

${ }^{1}$ Fiscal year begins in July.

2 Includes arrears. 
Table 3. Uganda: Monetary Accounts, 2005/06-2008/09

(U Sh billions; end of period, unless otherwise indicated)

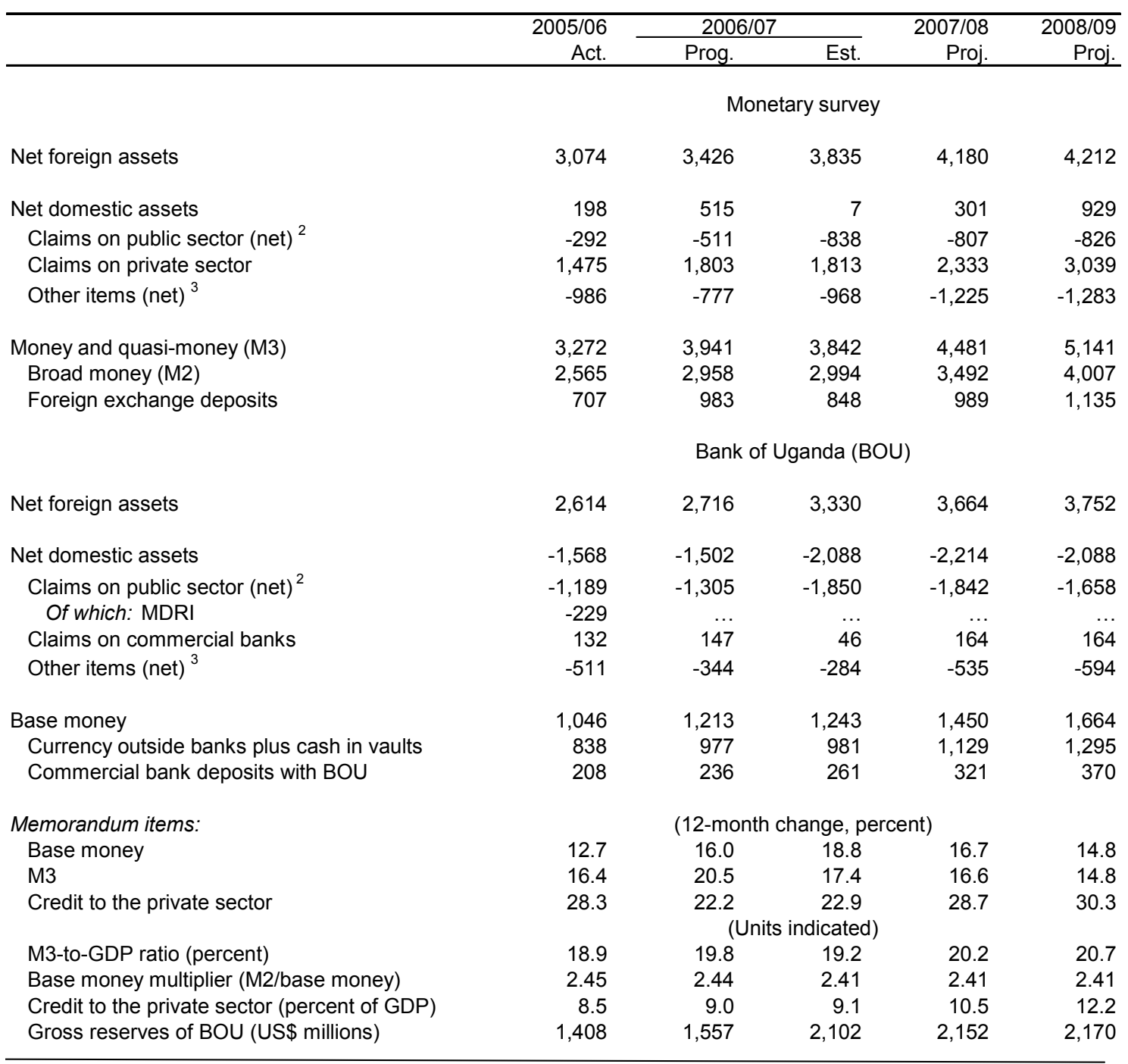

Sources: Ugandan authorities; and IMF staff estimates and projections.

${ }^{1}$ Fiscal year begins in July.

${ }^{2}$ The public sector includes the central government, public enterprises, and the local government.

${ }^{3}$ Including valuation and the BOU's claims on private sector. 
Table 4. Uganda: Balance of Payments, 2005/06-2011/12 1

(US\$ millions)

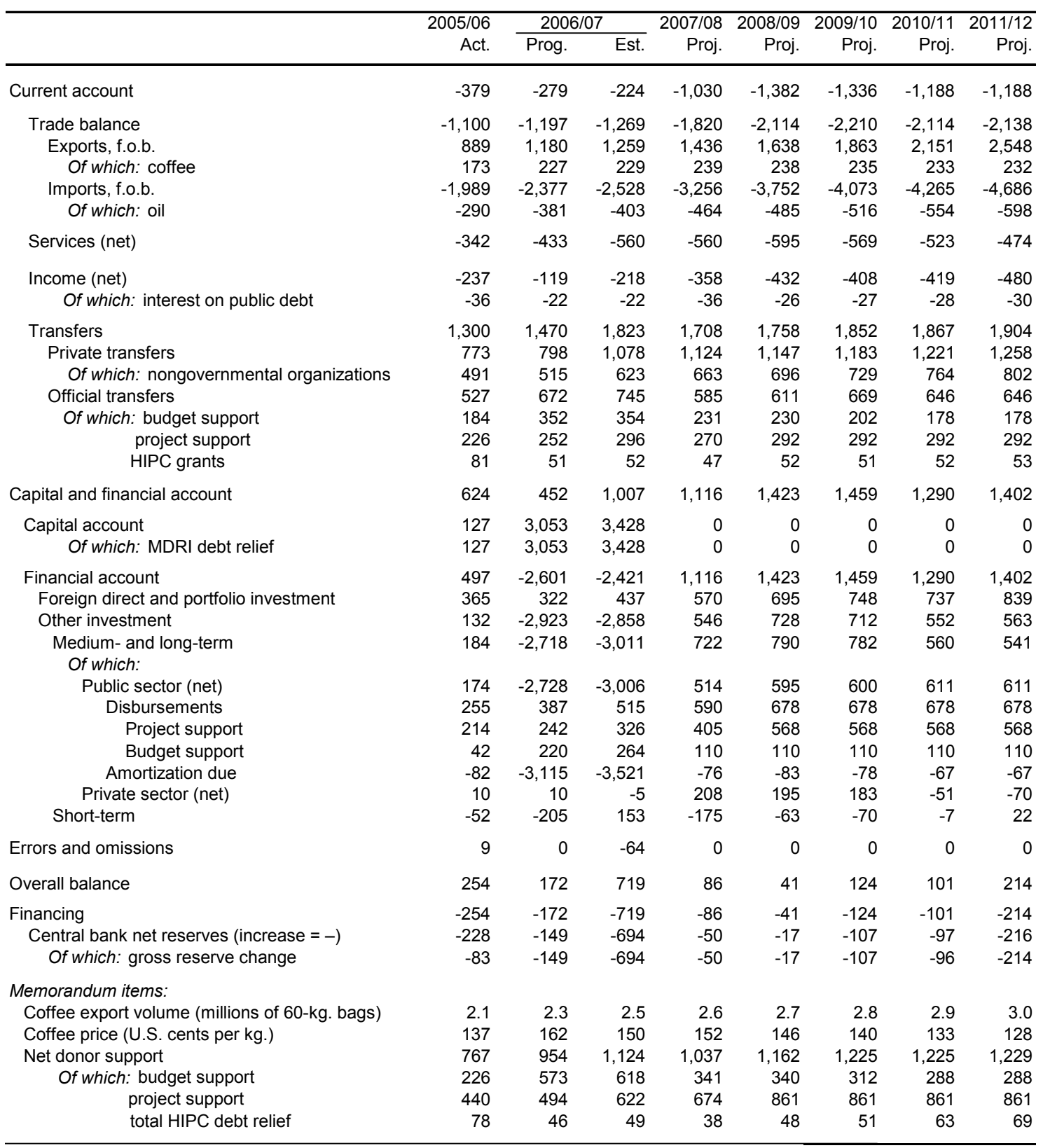

Sources: Ugandan authorities; and IMF staff estimates and projections.

${ }^{1}$ Fiscal year begins on July 1. 
Table 5. Uganda: Medium-Term Macroeconomic Framework, 2005/06-2009/10 ${ }^{1}$

\begin{tabular}{|c|c|c|c|c|c|}
\hline & $\begin{array}{r}2005 / 06 \\
\text { Act. }\end{array}$ & $\begin{array}{r}2006 / 07 \\
\text { Est. }\end{array}$ & $\begin{array}{r}2007 / 08 \\
\text { Proj. }\end{array}$ & $\begin{array}{r}2008 / 09 \\
\text { Proj. }\end{array}$ & $\begin{array}{r}2009 / 10 \\
\text { Proj. }\end{array}$ \\
\hline \multicolumn{6}{|l|}{ National income and prices } \\
\hline Real GDP (percent change) & 5.1 & 6.5 & 7.1 & 7.0 & 7.0 \\
\hline Per capita GDP (2004/05 US\$) & 333 & 343 & 356 & 370 & 383 \\
\hline Underlying average inflation (percent change) & 5.2 & 7.8 & 4.8 & 4.0 & 4.0 \\
\hline Gross domestic investment (percent of GDP) & 23.4 & 24.5 & 27.6 & 28.4 & 26.7 \\
\hline \multicolumn{6}{|l|}{$\begin{array}{l}\text { External sector } \\
\quad \text { (percent of GDP, unless otherwise indicated) }\end{array}$} \\
\hline Current account balance (including grants) & -4.0 & -2.0 & -8.0 & -9.5 & -8.4 \\
\hline Net donor inflows & 8.1 & 10.0 & 8.1 & 8.0 & 7.7 \\
\hline Current account balance (excluding grants) & -9.5 & -8.6 & -12.6 & -13.7 & -12.5 \\
\hline NPV of debt-to-exports ratio (percent) & -- & -- & 48.8 & 58.6 & 61.4 \\
\hline \multicolumn{6}{|l|}{ Government budget and debt (percent of GDP) } \\
\hline Revenue & 13.1 & 13.4 & 14.1 & 14.6 & 15.1 \\
\hline Grants & 6.5 & 6.3 & 4.3 & 3.9 & 3.4 \\
\hline Total expenditure and net lending & 20.4 & 21.9 & 21.8 & 22.8 & 22.2 \\
\hline Overall balance (including grants) & -0.8 & -2.3 & -3.4 & -4.2 & -3.7 \\
\hline Overall balance (excluding grants) & -7.3 & -8.6 & -7.7 & -8.2 & -7.1 \\
\hline Stock of domestic debt & 9.1 & 9.9 & 9.9 & 7.9 & 6.5 \\
\hline Credit to the private sector (percent of GDP) & 8.5 & 9.1 & 10.5 & 12.2 & 13.5 \\
\hline \multirow{2}{*}{\multicolumn{6}{|c|}{$\begin{array}{l}\text { Gross foreign exchange reserves } \\
\text { (months of next year's imports) }\end{array}$}} \\
\hline & 4.7 & 5.8 & 5.2 & 4.8 & 4.8 \\
\hline
\end{tabular}

Sources: Ugandan authorities; and IMF staff estimates and projections.

${ }^{1}$ Fiscal year begins in July. 


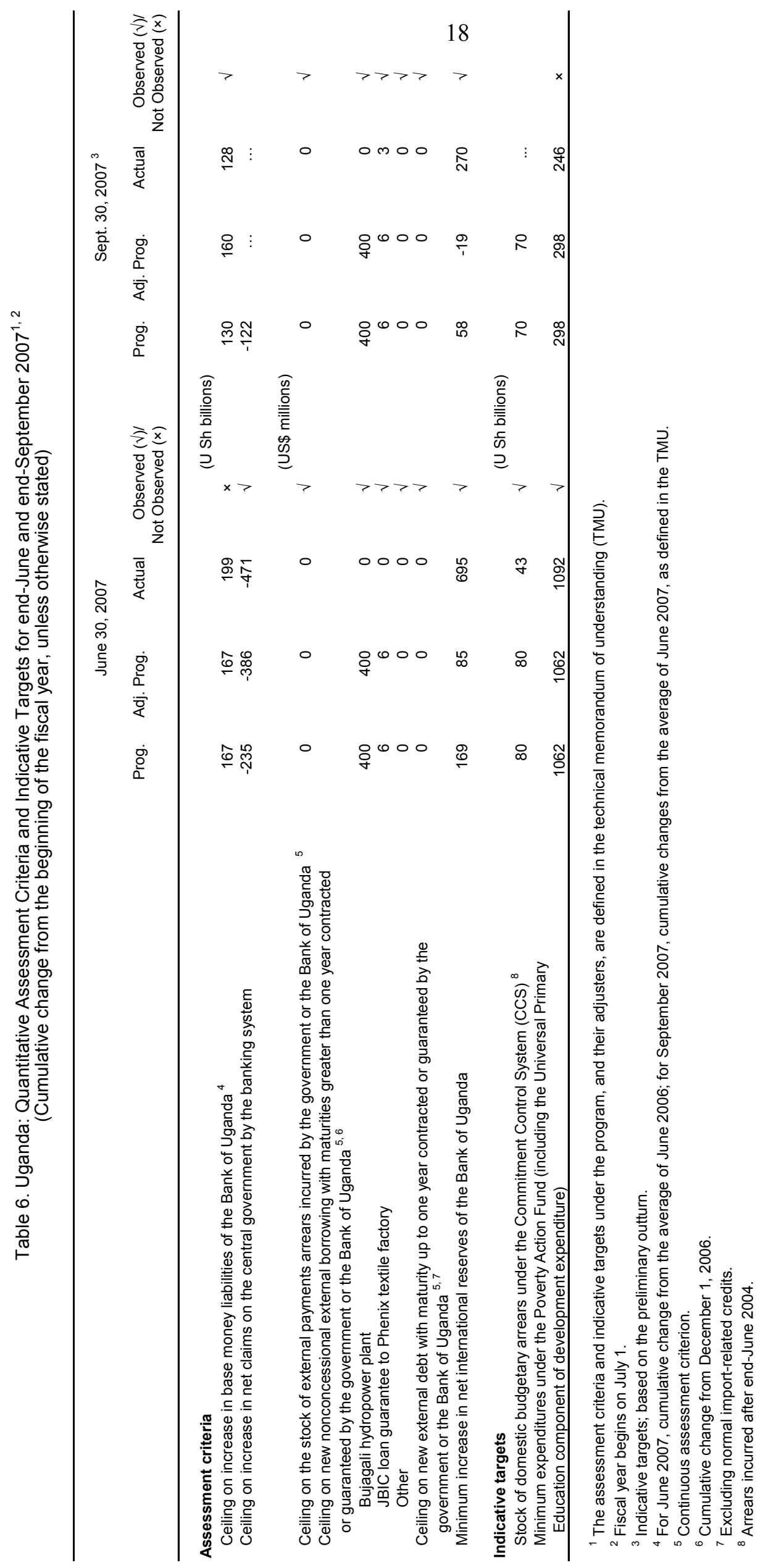


Table 7. Uganda: Structural Assessment Criteria and Benchmarks ${ }^{1}$

Policy Measure

Date of

Implementation

Implementation Status

\section{Structural Assessment Criteria}

1. For $2007 / 08$ budget, allocate U Sh 280 billion for payments End-June $2007 \quad$ Completed of group (A) verified domestic arrears. ${ }^{2}$

2. Verify the amount of pension payments due and prepare

End-May $2007 \quad$ Completed a review of pension payment and accounting systems, and make recommendations for changes if necessary.

3. Finalize and publish the Government of Uganda Debt Strategy

End-December 2007 On track

4. Submit to cabinet a policy paper outlining the establishment of a new regulatory framework for financial institutions not under the statutory supervision of the BOU.

End-January 2008

Revised $^{3}$ Implementation date shifted to allow These financial institutions will include private and public government to receive pension funds, insurance companies, and the Uganda Development Bank. technical assistance and coordinate work with the BOU.

\section{Structural Benchmarks}

5. Introduce a system to verify overdue payments from all relevant government entities within 8 weeks of the end of

End-April 2007

Completed each quarter.

6. Submit to Cabinet new insolvency legislation

End-June 2007

Completed

7. Begin procurement process for the national identity card system.

End-February 2008

Revised $^{3}$

Action made more specific and made assessment criterion

8. Roll out Integrated Personnel and Payroll System in pilot ministries.

End-June 2008

Revised $^{3}$

Action made

assessment criterion.

${ }^{1}$ Assessment criteria also apply on a continuous basis to the standard provisions on the exchange and trade issues that apply to programs supported by the Fund's financial resources.

${ }^{2}$ Group (A) arrears comprise the stock of pre-CCS, non-CCS, and CCS arrears incurred before end-June 2004.

${ }^{3}$ See Table 2 in the MEFP. 
Table 8. Uganda: Selected Banking Sector Information, June 2004-June 2007

\begin{tabular}{|c|c|c|c|c|c|c|c|}
\hline & \multicolumn{2}{|c|}{2004} & \multicolumn{2}{|c|}{2005} & \multicolumn{2}{|c|}{2006} & \multirow{2}{*}{$\begin{array}{l}2007 \\
\text { June }\end{array}$} \\
\hline & June & Dec. & June & Dec. & June & $\overline{\text { Dec. }}$ & \\
\hline & \multicolumn{6}{|c|}{ (U Sh billions) } & \\
\hline Adjusted assets & 3,184 & 3,294 & 3,526 & 3,659 & 3,841 & 4,422 & 4,629 \\
\hline Liquid assets & 1,279 & 1,538 & 1,374 & 1,558 & 1,179 & 1,500 & 1,460 \\
\hline Tier I & 276 & 313 & 311 & 348 & 379 & 444 & 480 \\
\hline Tier II & 32 & 30 & 26 & 32 & 36 & 40 & 35 \\
\hline Total capital & 309 & 343 & 337 & 380 & 416 & 484 & 515 \\
\hline Risk-weighted assets (RWA) & 1,624 & 1,674 & 1,881 & 2,076 & 2,271 & 2,686 & 2,563 \\
\hline Nonperforming assets (NPA) & 14 & 21 & 33 & 29 & 41 & 50 & 60 \\
\hline Loans and advances & 884 & 977 & 1,114 & 1,258 & 1,450 & 1,703 & 1,768 \\
\hline Foreign exchange advances & 218 & 267 & 327 & 384 & 450 & 463 & 465 \\
\hline Foreign exchange depostis & 806 & 817 & 838 & 786 & 815 & 949 & 937 \\
\hline \multirow[t]{2}{*}{ Deposits } & 2,396 & 2,438 & 2,549 & 2,595 & 2,741 & 2,961 & 3,145 \\
\hline & \multicolumn{6}{|c|}{ (Percent) } & \\
\hline Return on average assets & 5.0 & 4.3 & 3.4 & 3.6 & 3.5 & 3.4 & 3.9 \\
\hline Core capital/ RWA & 17.0 & 18.7 & 16.5 & 16.8 & 16.7 & 16.5 & 18.7 \\
\hline Total capital/ RWA & 19.0 & 20.5 & 17.9 & 18.3 & 18.3 & 18.0 & 20.1 \\
\hline NPAs/total advances & 1.6 & 2.2 & 2.9 & 2.3 & 2.8 & 2.9 & 3.4 \\
\hline Loan loss provision/ NPA & 139.6 & 97.8 & 78.0 & 103.8 & 93.7 & 74.4 & 69.3 \\
\hline Liquid assets/ total deposits & 53.4 & 63.1 & 53.9 & 60.0 & 43.0 & 50.7 & 46.4 \\
\hline Advances/ deposits & 36.9 & 37.4 & 43.7 & 48.5 & 52.9 & 57.5 & 56.2 \\
\hline Foreign exchange exposure/ core capital ${ }^{1}$ & 4.7 & -2.0 & -2.7 & -2.7 & -8.7 & -7.4 & -2.5 \\
\hline Foreign exchange advances/ foreign exchange deposits & 27.0 & 32.6 & 39.1 & 48.8 & 55.2 & 48.8 & 49.6 \\
\hline
\end{tabular}

Source: Ugandan authorities.

${ }^{1}$ Foreign exchange exposure is calculated using the short-hand method. 
Table 9. Uganda: Millennium Development Goals

\begin{tabular}{|c|c|c|c|c|}
\hline & 1990 & 1995 & 2001 & 2005 \\
\hline Eradicate extreme poverty and hunger. & \multicolumn{4}{|c|}{2015 target $=$ halve $1990 \$ 1$ a day poverty and malnutrition rates } \\
\hline Percentage share of income or consumption held by poorest 20 percent & $\ldots$ & $\ldots$ & 5.9 & $\ldots$ \\
\hline Prevalence of child malnutrition (percent of children under 5) & 23.0 & 25.5 & 22.8 & $\ldots$ \\
\hline Population below minimum level of dietary energy consumption (percent) & 23.0 & 25.0 & 19.0 & $\cdots$ \\
\hline Achieve universal primary education. & \multicolumn{4}{|c|}{2015 target $=$ net enrollment to 100} \\
\hline Net primary enrollment ratio (percent of relevant age group) & $\ldots$ & 87.3 & $\ldots$ & $98.4^{1}$ \\
\hline Youth literacy rate (percent of ages 15-24) & 70.1 & 74.7 & 79.4 & 77.0 \\
\hline Promote gender equality. & \multicolumn{4}{|c|}{2015 target $=$ education ratio to 100} \\
\hline Ratio of girls to boys in primary and secondary education (percent) & 76.8 & 81.0 & 95.0 & 96.0 \\
\hline Ratio of young literate females to males (percent of ages 15-24) & 75.8 & 80.4 & 85.0 & 86.0 \\
\hline Share of women employed in the nonagricultural sector (percent) & 43.2 & $\ldots$ & $\ldots$ & $\ldots$ \\
\hline Proportion of seats held by women in national parliament (percent) & 12.0 & 17.0 & 18.0 & 24.0 \\
\hline Reduce child mortality. & \multicolumn{4}{|c|}{2015 target $=$ reduce 1990 under -5 mortality by two-thirds } \\
\hline Under-5 mortality rate (per 1,000 ) & 160.0 & 156.0 & 145.0 & 136.0 \\
\hline Infant mortality rate (per 1,000 live births) & 93.0 & 92.0 & 85.0 & 79.0 \\
\hline Immunization, measles (percent of children under 12 months) & 52.0 & 57.0 & 61.0 & 86.0 \\
\hline Improve maternal health. & \multicolumn{4}{|c|}{2015 target $=$ reduce 1990 maternal mortality by three-fourths } \\
\hline Maternal mortality ratio (modeled estimate, per 100,000 live births) & $\ldots$ & $\ldots$ & 880.0 & $\ldots$ \\
\hline Births attended by skilled health staff (percent of total) & 38.3 & 37.8 & 39.0 & $\cdots$ \\
\hline Combat HIVIAIDS, malaria, and other diseases. & \multicolumn{4}{|c|}{2015 target $=$ halt, and begin to reverse, AIDS, etc. } \\
\hline Prevalence of HIV, female (percent of ages 15-24) & $\ldots$ & $\ldots$ & 4.6 & 5.0 \\
\hline Contraceptive prevalence rate (percent of women ages 15-49) & 4.9 & 14.8 & 22.8 & $\ldots$ \\
\hline Number of children orphaned by HIVIAIDS (thousands) & $\ldots$ & $\ldots$ & 880.0 & $\ldots$ \\
\hline Incidence of tuberculosis (per 100,000 people) & 161.1 & $\ldots$ & 324.0 & 369.0 \\
\hline Tuberculosis cases detected under DOTS (percent) ${ }^{2}$ & $\ldots$ & $\ldots$ & 44.4 & 45.0 \\
\hline Ensure environmental sustainability. & \multicolumn{4}{|c|}{2015 target $=$ various } \\
\hline Forest area (percent of total land area) & 25.9 & $\cdots$ & 21.3 & 18.0 \\
\hline Nationally protected areas (percent of total land area) & $\ldots$ & 9.7 & 9.7 & 32.6 \\
\hline $\mathrm{CO} 2$ emissions (metric tons per capita) & 0.0 & 0.0 & 0.1 & 0.1 \\
\hline Access to an improved water source (percent of population) & 45.0 & $\cdots$ & 52.0 & 60.0 \\
\hline Access to improved sanitation (percent of population) & $\ldots$ & $\cdots$ & 79.0 & 43.0 \\
\hline Develop the Global Partnership for Development. & \multicolumn{4}{|c|}{2015 target $=$ various } \\
\hline Fixed line and mobile telephones (per 1,000 people) & 1.6 & 2.0 & 13.5 & 56.0 \\
\hline Personal computers (per 1,000 people) & $\cdots$ & 0.5 & 2.8 & 9.0 \\
\hline \multicolumn{5}{|l|}{ General indicators } \\
\hline Population (millions) & 17.8 & 20.9 & 25.1 & 28.8 \\
\hline Adult literacy rate (percent of people ages 15 and over) & 56.1 & $\ldots$ & $\ldots$ & 67.0 \\
\hline Total fertility rate (births per woman) & 7.2 & 6.9 & $\cdots$ & 7.1 \\
\hline Life expectancy at birth (years) & 45.7 & 43.1 & $\ldots$ & 50.0 \\
\hline
\end{tabular}

Source: World Development Indicators database, April 2007.

1 Data for 2004.

2 Percentage of estimated new infectious tuberculosis cases detected under the directly observed treatment, short-course case detection and treatment strategy. 


\section{APPENDIX I-UGANDA: LETTER OF INTENT}

Kampala, Uganda

November 26, 2007

Mr. Dominique Strauss Kahn

Managing Director

International Monetary Fund

Washington, D.C. 20431

Dear Mr. Strauss Kahn:

On behalf of the Government of Uganda, I would like to inform you of the progress we have made under our economic program backed by the International Monetary Fund's Policy Support Instrument (PSI) and transmit the attached Memorandum of Economic and Financial policies (MEFP), which sets out the objectives and policies that the Government intends to pursue in the short and medium term. The policies outlined in the MEFP are based on addressing Uganda's infrastructure needs in an environment of continued fiscal consolidation and implementation of the broader policy agenda as envisaged in the Poverty Eradication Action Plan.

All assessment criteria for the first review under the PSI were observed, save for the nonobservance of the ceiling on base money. The Government implemented vigorous measures to alleviate the electricity shortages, and macroeconomic performance and policies remained strong. Fiscal developments were broadly in line with the program objective of fiscal consolidation, and other monetary policy targets were met. The government requests a waiver of the missed assessment criterion, because the non-observance reflected unforeseen external factors. We have modified the program to limit such occurrences in the future.

The Government of Uganda believes that the policies set forth in the MEFP are adequate to achieve the objectives of our PSI program. Given our interest in macroeconomic stability, we stand ready to take additional measures as may be necessary to achieve needed objectives. Our PSI proposes assessment criteria for the performance target dates of endDecember 2007 and end-June 2008 for the third and fourth reviews, which are expected to be completed by end-April and end-October 2008, respectively. We stand ready to work with the Fund and other development partners in the implementation of our program and will consult in advance should revisions be contemplated to the policies contained in the PSI. 
The Government of Uganda authorizes the publication and distribution of this letter, its attachments, and all reports prepared by Fund staff regarding the current PSI review.

Sincerely yours,

/s/

Dr. Ezra Suruma

Minister of Finance, Planning, and Economic Development 


\section{APPENDIX I-ATTACHMENT I}

\section{Uganda: Memorandum of Economic And Financial Policies}

\section{UPDATE}

1. The Government of Uganda remains committed to sustained macroeconomic stability, economic growth, and poverty reduction. This updated Memorandum of Economic and Financial Policies (MEFP), summarizes the Government's strategy to achieve these goals as set out in the Poverty Eradication Action Plan (PEAP). The Government and the International Monetary Fund (IMF) are cooperating on the economic program through a three-year Policy Support Instrument (PSI). This MEFP describes performance under the program through September 2007, specific policies and targets for 2007/08, and medium-term objectives.

\section{Performance Under the PSI}

2. Most program targets have been met. Fiscal performance in 2006/07 was better than programmed, with revenue collections exceeding the target, and, accordingly, the ceiling on net claims on government by the banking system was observed. Base money exceeded its end-June program ceiling following large portfolio inflows at the end of 2006/07. This overshoot was temporary, and by mid-August, base money was brought back to the targeted path. The floor on the stock of net international reserves of the BOU was exceeded by a substantial margin. The indicative targets on the stock of domestic budgetary arrears under the Commitment Control System (CCS) and on poverty alleviation expenditure were observed. Structural measures are on track, including the allocation of more than one percent of GDP to arrears repayment.

\section{Objectives and Policies Looking Forward}

\section{A. Fiscal Policy}

3. Our budget for $\mathbf{2 0 0 7 / 0 8}$ is guided by our medium-term expenditure framework and our prudent approach to fiscal policy. Accordingly, we will aim to continue reducing the central government deficit (excluding grants) so that the private sector can lead economic growth and poverty reduction. At the same time, our 2007/08 budget will increase infrastructure spending and put emphasis on provisions for Government of Uganda counterpart funding for donor-financed infrastructure projects.

4. Since the $2007 / 08$ budget was approved, several immediate spending pressures have emerged. These include (i) infrastructure and other projects related to the 2007 Commonwealth Heads of Government Meetings (CHOGM), (ii) recent flooding in the eastern and northern regions, and (iii) higher subsidies to the electricity sector due to unanticipated increases in global oil prices. The new costs are uncertain at this time and to prepare for these spending pressures within the budget envelope, we have frontloaded cash 
releases for (i) and (ii) above in Q1 and Q2 of 2007/08.(but protecting the poverty action fund). However, we may need to increase our spending envelope later in the year.

\section{The policy of annually increasing tax collections by 0.5 percent of GDP over}

the medium term remains in place. We were on track with this objective in 2006/07, raising the ratio by 0.3 percentage points despite the electricity crisis and plan to remain on track this year through the ongoing modernization at the Uganda Revenue Authority and a few changes in taxes that have been approved by Parliament. We also plan to produce a tax procedure code that will help individuals and businesses better understand their tax obligations.

\section{The Government has announced the introduction of tax incentives for qualified} exporters. Attracting investment to Uganda is a key part of the value addition strategy to bring more employment opportunities to Ugandans. The revenue loss due to tax incentives is expected to be modest, around 0.1 percent of GDP in 2007/08. We will avoid granting enterprise-based discretionary tax preferences, and implementation will take place as budgetary resources permit and taking into account the URA's capacity to monitor compliance. These tax holidays are consistent with tax policies in our EAC partners.

\section{We remain committed to limiting the accumulation of new domestic arrears and are making some adjustments to our strategy.}

a. The IFMS has been rolled out to all of central government and will be rolled out to selected local governments, where feasible, as a measure to control accumulation of arrears.

b. All commitments made against the Accounting warrant, including those not backed by cash, will be captured in the IFMS CCS module. Starting in March 2008, to control the accumulation of CCS arrears, expenditures committed outside the IFMS system for both IFMS and non-IFMS votes will not be recognized by the Accountant General as arrears and therefore will not be programmed for payment in future budgets by MoFPED. Efforts will be made to ensure that clearance of category B arrears takes the first call on resources availed on quarterly basis.

c. Long-term commitments (pension, rent, contributions to international organizations) or unplanned events (e.g. court awards) will be handled through realistic budgeting and review of policy.

d. The Ministry of Public Service will implement the new Integrated Personnel and Payroll System in three Commissions (Public Service Commission, Health Service Commission, Education Service Commission), Ministries (Ministry of Finance, Ministry of Health, Ministry of Public Service, Ministry of Education), and Local Governments (Lira and Jinja Districts) by May 2008. This should improve payroll and pension records and ensure accurate payroll and pension figures. 
e. The Ministry of Finance, Planning and Economic Development, in conjunction with the Ministry of Foreign Affairs, will submit to Cabinet an updated list of international subscriptions and related host ministries to Cabinet for verification and approval. Further, the Ministry of Finance will advise all ministries that, starting with the 2007/08 financial year, subscription obligations will be met within their own budgets;

These steps should help contain arrears accumulation. We endeavor to adequately provide funding for statutory expenditures, and commitments for cofinancing of development projects in the upcoming budget.

8. We will continue to move ahead with measures to improve fiscal policy and its implementation. In addition to those outlined in the MEFP dated 17 May 2007, we will extend our medium-term planning period from three to five years, build our capacity to carry out debt sustainability analysis, move forward with public service pay reform (as resources permit), and look for ways of delivering government services more efficiently. These efforts should help us free resources for critical infrastructure investment and better target these within our debt strategy.

\section{B. Monetary and Financial Sector Policies}

\section{We remain committed to keeping annual average underlying inflation below}

five percent. Our monetary policy will remain anchored by base money. However, flexibility in base money will be allowed in order to enable the BOU to address unanticipated currency inflows or other shifts in money demand. To implement this, the Net Domestic Assets (NDA) of the BOU will become an assessment criterion under the PSI, while the existing assessment criterion on base money will become an indicative target. We will strive to maintain the programmed path of base money barring any acute shocks. Deviations from the monthly average target will be limited to plus or minus five percent and only on account of external balance of payments shocks as evidenced by instability in the foreign exchange market.

10. The BOU will continue to manage liquidity using an appropriate instrument mix. Subject to the conditions in the foreign exchange market, BOU will continue to use sales of foreign exchange to sterilize shilling liquidity injections arising largely from government expenditure. However, the BOU will rely more heavily on open market operations for liquidity management if the interbank foreign exchange market conditions do not allow it to sell in full the programmed foreign exchange.

\section{Government and the BOU are taking steps to increase financial} intermediation with the aim of reducing borrowing costs and boosting private investment. Uganda's financial sector comprises financial market (mainly commercial banks and money and foreign exchange markets), non-deposit-taking institutions (pension funds, insurance companies), and microfinance institutions. Our strategy represents a comprehensive and concerted effort by both the BOU and the Government to enhance financial intermediation by developing all elements of the financial sector. The BOU is 
taking the lead in developing further the Uganda's financial market in order to enhance the availability and affordability of its services. Government in turn is working on (i) mobilizing the resources of the non-deposit-taking institutions in order to enhance the provision of long-term credit and (ii) providing capacity building and proper supervision to the microfinance institutions in order to expand the access to the financial services to segments of the population that are currently outside of the formal financial sector. Specific measures by Government include:

a. Submit to Cabinet legislation to regulate pension and other non deposit taking financial institutions. This will help protect pensioners and investors and also bolster sources of longer-term savings for capital investment. Changes to the public pension system would be considered after this general legislation is in place, while safeguarding social security protection and promoting financial market deepening.

b. Issue a tender to select the provider for the national identity card system for the purpose of tracking individual borrowing and repayment records. These will help lower the risk of lending, especially to SMEs and individuals.

As part of the Monetary Affairs Committee (MAC) of the EAC, the BOU on its part has drafted a five-year financial market development plan and has received comments from the key stakeholders. These will soon be incorporated into the plan. The plan represents an approach to addressing the current limitations in the Uganda's financial markets by identifying gaps and constraints. It also sets a foundation for implementation of proposed recommendations and will incorporate the different roles the stakeholders will play.

\section{The BOU is moving forward with preparations for a possible move to inflation} targeting. A key impetus has been the recent instability in money demand. The BOU is pushing forward its research program and is working with UBOS to produce high frequency data. The BOU and Government will work together to ensure that both parties are able to meet their respective obligations for inflation targeting.

\section{Energy and Infrastructure}

\section{The Government attaches the utmost importance to addressing infrastructure} deficiencies. Reflecting this, agriculture, infrastructure development, including transportation, electricity, and water have been given priority in the 2007/08 budget and in the medium term.

14. We are implementing our two stage strategy to boost electric power generating capacity. In the near-term Government will continue to support the private sector by carrying some of the cost of temporary generators. For the medium term, the final agreements for Bujagali are expected to be signed and full scale construction will begin soon after. Government is planning additional dam projects. We will ensure that these are the least cost options to secure needed capacity, financing is in accordance with our debt strategy, and procurement is in line with Uganda law. 
15. We recognize that road projects are lagging behind our needs and we are considering options to speed up repairs and new construction. One possibility is to utilize "turnkey" projects where one development partner would provide a completed road from planning, engineering, financing, and construction and ready for ribbon cutting. As with power sector projects, any work considered for this approach would be in compliance with our debt strategy and in compliance with our laws. We will also use the Road Fund to ring fence resources for road maintenance.

\section{Prospects for commercial oil production have improved significantly, and}

production could begin in the next several years. We recognize the challenges associated with windfall oil revenues, including their potentially negative impact on macroeconomic stability, fiscal sustainability, and development of the non-oil economy. Government is developing a national strategy to ensure that the oil wealth is used wisely. This strategy will include our commitment to manage these resources transparently and to use them in a way consistent with macroeconomic stability. The IMF has committed to provide assistance in these areas. We anticipate having the strategy and accompanying legislation in place by end-June 2008.

\section{Other Issues}

17. Together with our regional counterparts, we are taking steps to facilitate closer integration among the members of the East African Community. On the agenda are closer economic ties, joint approach to customs policy and investment incentives, and eventual monetary union.

18. The Government of Uganda has requested technical assistance in the following four areas: oil (tax policy design); balance of payments (collection and analysis of data on informal cross-border trade and on offshore investments); national accounts; and inflation targeting. The IMF has committed to providing this assistance. The Government of Uganda has also requested TA on supervision of non-bank financial institutions, and the IMF may be able to accommodate this request. 


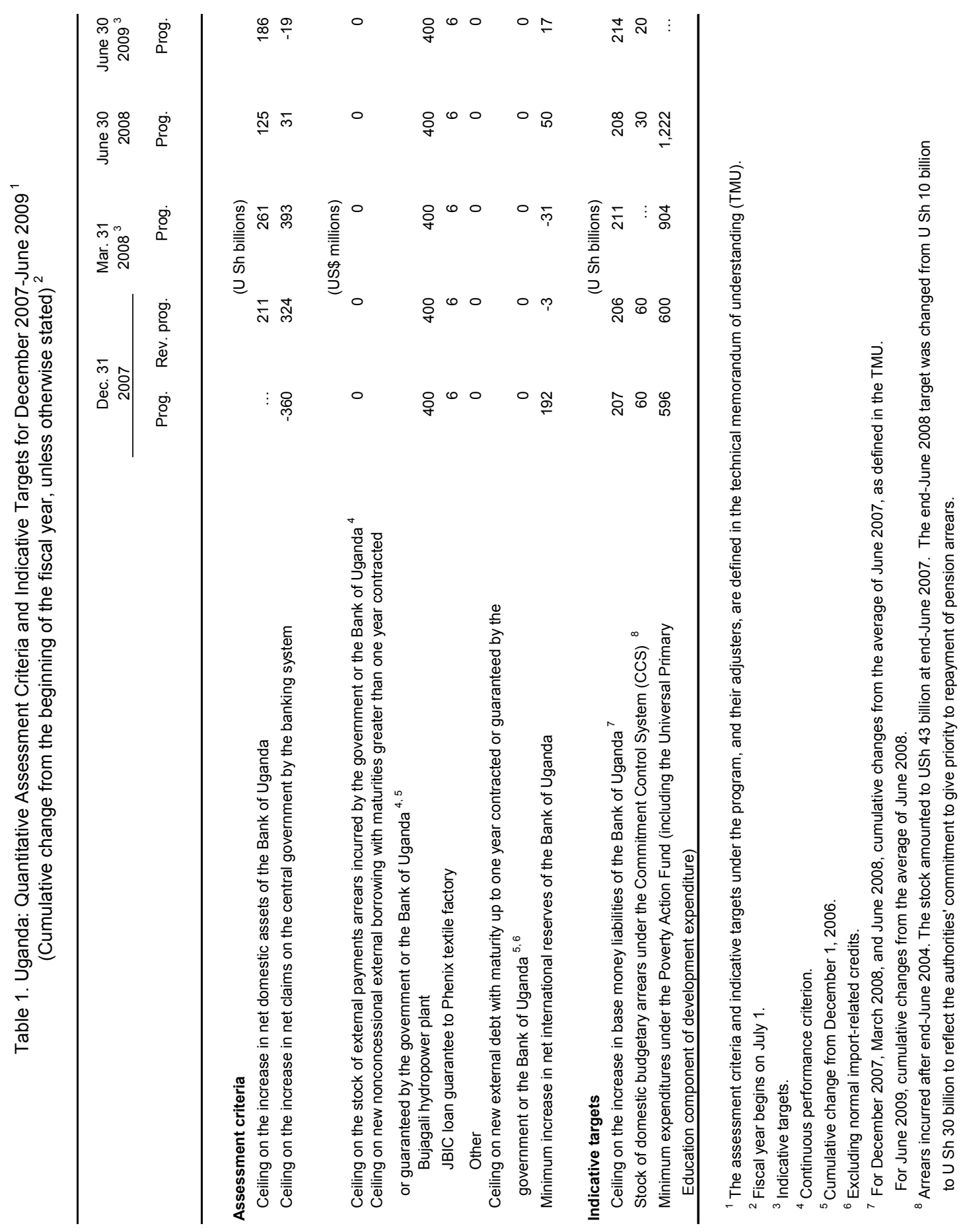


Table 2. Uganda: Structural Assessment Criteria and Benchmarks ${ }^{1}$

Policy Measure
Structural Assessment Criteria

1. Finalize and publish the Government of Uganda Debt Strategy

End-December 2007

2. Submit to cabinet a policy paper outlining the establishment of a

End-June 2008 new regulatory framework for financial institutions not under the statutory supervision of the BOU. These financial institutions will include private and public pension funds, and the Uganda Development Bank.

3. Implement pilot Integrated Personnel and Payroll System in three

End-May 2008 Commissions (Public Service Commission, Health Service Commission, Education Service Commission), Ministries (Ministry of Finance, Ministry of Health, Ministry of Public Service, Ministry of Education), and Local Governments (Lira and Jinja Districts).

4. For 2008/09 budget, allocate U Sh 300 billion for payments of

End-June 2008 verified group $(\mathrm{A})$ domestic arrears, with priority given to pension arrears. ${ }^{2}$

5. Issue a tender to select the provider for the national identity card system.

End-June 2008

\section{Structural Benchmarks}

6. The BOU, in consultation with other members of the Monetary Affairs Committee of the EAC, will finalize a comprehensive draft financial market development strategy.

7. The Ministry of Finance, in conjunction with the Ministry of Foreign Affairs, will submit to Cabinet the complete list of international subscriptions and the related payment obligations.

8. Update national energy (Oil) policy to include macroeconomic policy

End-June 2008 options.

\footnotetext{
${ }^{1}$ Assessment criteria also apply on a continuous basis to the standard provisions on the exchange and trade issues that apply to programs supported by the Fund's financial resources.

${ }^{2}$ Group (A) arrears comprise the stock of pre-CCS, non-CCS, and CCS arrears incurred before endJune 2004.
} 


\section{APPENDIX I-ATTACHMENT II}

\section{Uganda: TeChNicAL MEMORANDUM OF UNDERSTANDING}

\section{A. Introduction}

1. This memorandum defines the targets described in the memorandum of economic and financial policies (MEFP) for the July 2006-June 2009 financial program supported by the IMF Policy Support Instrument (PSI), and sets forth the reporting requirements under the instrument.

\section{B. Net Foreign Assets (NFA) and Net Domestic Assets (NDA) of the Bank of Uganda (BOU)}

2. The net foreign assets of the BOU are defined as the monthly average (based on daily data) of foreign assets minus foreign liabilities, and include all foreign claims and liabilities of the central bank. The monthly average values of all foreign assets and liabilities will be converted into U.S. dollars at each test date using the average cross exchange rates for June 2007 for the various currencies and then converted into Uganda shillings using the average U.S. dollar-Uganda shilling exchange rate for June 2007.

\begin{tabular}{|l|l|}
\hline \multicolumn{2}{|c|}{ Program Exchange Rates (US\$ per currency unit, unless indicated otherwise) } \\
\hline Euro & 1.3417 \\
\hline British pound & 1.9843 \\
\hline Japanese Yen & 0.0082 \\
\hline Kenya shilling & 0.0150 \\
\hline Tanzania shilling & 0.0008 \\
\hline SDR & 1.5113 \\
\hline Uganda shilling (per US\$1) & $1,645.7$ \\
\hline
\end{tabular}

3. Net domestic assets (NDA) of the Bank of Uganda (BOU) are defined as the monthly average (based on daily data) of base money (defined below) less net foreign assets of the BOU (as defined in para. 2). Based on this definition, the NDA limits will be cumulative changes from the average of June 2007 to the average of December 2007, March 2008 and June 2008. The respective cumulative changes are increases of Shs 210.6 billion, Shs261.2 billion and Shs125.6 billion. 


\begin{tabular}{|c|c|c|c|}
\hline \multicolumn{4}{|l|}{ (In billions of shillings) } \\
\hline & Dec 2007 & Mar 2008 & Jun 2008 \\
\hline Cumulative change in base money & 206.3 & 210.7 & 207.6 \\
\hline Cumulative change in NFA & -4.3 & -50.5 & 82.3 \\
\hline Cumulative change in NDA & 210.6 & 261.2 & 125.3 \\
\hline
\end{tabular}

\section{B. Base Money}

4. Base money is defined as the sum of currency issued by Bank of Uganda (BOU) and the commercial banks' deposits in the BOU. The commercial bank deposits include the statutory required reserves and excess reserves held at the BOU and are net of the deposits of closed banks at the BOU and Development Finance Funds (DFF) contributed by commercial banks held at the BOU. The base money limits will be cumulative changes from the daily average of June 2007 to the daily average of December 2007, March 2008 and June 2008, and cumulative changes from the daily average of June 2008 to the daily average of June 2009.

\section{Net Claims on the Central Government by the Banking System}

5. Net claims on the central government (NCG) by the banking system is defined as the difference between the outstanding amount of bank credits to the central government and the central government's deposits with the banking system, excluding deposits in administered accounts and project accounts with the banking system, including the central bank. Credits comprise bank loans and advances to the government and holdings of government securities and promissory notes. Central government's deposits with the banking system include the full amount of IMF MDRI. NCG will be calculated based on data from balance sheets of the monetary authority and commercial banks as per the monetary survey. The quarterly limits on the change in NCG by the banking system will be cumulative beginning end-June in the previous fiscal year.

\section{Net International Reserves of the Bank of Uganda}

6. Net international reserves (NIR) of the BOU are defined for program monitoring purpose as reserve assets of the BOU net of short-term external liabilities of the BOU. Reserve assets are defined as external assets readily available to, and controlled by, the BOU and exclude pledged or otherwise encumbered external assets, including, but not limited to, assets used as collateral or guarantees for third-party liabilities. Short-term external liabilities are defined as liabilities to nonresidents, of original maturities less than one year, contracted by the BOU and include outstanding IMF purchases and loans. 
7. For program-monitoring purposes, reserve assets and short-term liabilities at the end of each test period will be calculated in U.S. dollars by converting them from their original currency denomination at program exchange rates (as specified in para. 2).

\section{E. Ceiling on Domestic Budgetary Arrears of the Central Government}

8. The stock of domestic payment arrears under the Commitment Controls System (CCS) will be monitored on a quarterly basis. Domestic payments arrears under the CCS are defined as the sum of all bills that have been received by a central government spending unit or line ministry delivered in that quarter, and for which payment has not been made within 30 days under the recurrent expenditure budget (excluding court awards) or the development expenditure budget. For the purpose of program monitoring, the quarterly CCS reports, which will include arrears accumulated at IFMIS and non-IFMIS sites, prepared by the Internal Audit and Inspection Office will be used to monitor arrears. Arrears can be cleared in cash or through debt swaps.

9. The payments of pre-CCS, non-CCS, and CCS arrears accumulated up to end-June 2004 ("group A arrears") are covered by specific budget allocations for 2006/07 and 2007/08. The program ceiling on the stock of CCS arrears only covers accumulation of arrears after end-June 2004 ("group B arrears"). According to the verified report prepared by the Internal Audit and Inspection Office, this stock of arrears is estimated at U Sh 43 billion as of June 2007.

\section{F. Adjusters}

10. The NDA and NIR targets are based on program assumptions regarding budget support, assistance provided under the Heavily Indebted Poor Countries (HIPC) Initiative and the Multilateral Debt Relief Initiative (MDRI), external debt-service payments, and automatic access by commercial banks to the BOU's rediscount and discount window facilities. The NCG target, in addition to being based on the aforementioned assumptions, is also based on assumptions regarding domestic nonbank financing of central government fiscal operations. In addition, the NDA target depends on the legal reserve requirements on deposits in commercial banks.

The Uganda shilling equivalent of budget support (grants and loans) plus HIPC Initiative assistance in the form of grants on a cumulative basis from July 1 of the fiscal year is presented under Schedule A. The ceilings on the cumulative increase in NDA and NCG will be adjusted downward (upward), and the floor on the cumulative increase in NIR of the BOU will be adjusted upward (downward) by the amount by which budget support, grants and loans, plus HIPC Initiative and MDRI assistance, exceeds (falls short of) the projected amounts. 


\begin{tabular}{|l|c|c|c|c|}
\hline \multicolumn{5}{|c|}{ Schedule A: Budget Support Plus Total HIPC Initiative Assistance } \\
(Cumulative billions of Uganda shillings, beginning July 1 of the fiscal year) \\
\hline Quarter & Dec. 31, 2007 & Mar.. 31, 2008 & June 30, 2008 & June 30, 2009 \\
\hline $\begin{array}{l}\text { Budget support, including } \\
\text { HIPC Initiative grants }\end{array}$ & 237 & 321 & 672 & 669 \\
\hline
\end{tabular}

11. The ceiling on the increases in NDA and NCG will be adjusted downward (upward) and the floor on the increase in NIR will be adjusted upward (downward) by the amount by which debt service due ${ }^{2}$ plus payments of external debt arrears less deferred payments (exceptional financing) falls short of (exceeds) the projections presented in Schedule B. Deferred payments are defined to be (i) all debt service rescheduled under the HIPC Initiative; and (ii) payments falling due to all non-HIPC Initiative creditors that are not currently being serviced by the authorities (that is, gross new arrears being incurred).

\begin{tabular}{|l|c|c|c|c|}
\hline \multicolumn{5}{|c|}{$\begin{array}{c}\text { Schedule B: Debt Service Due, Before HIPC Initiative Assistance } \\
\text { (Cumulative billions of Uganda shillings, beginning July 1 of the fiscal year) }\end{array}$} \\
\hline Quarter & Dec. 31, 2007 & Mar.. 31, 2008 & June 30, 2008 & June 30, 2009 \\
\hline $\begin{array}{l}\text { Debt service due before } \\
\text { HIPC, excluding } \\
\text { exceptional financing }\end{array}$ & 119 & 169 & 195 & 183 \\
\hline
\end{tabular}

12. The ceiling on the increase in NCG will be adjusted downward (upward) by any excess (shortfall) in nonbank financing ${ }^{3}$ less payment of domestic group A arrears relative to the programmed cumulative amounts presented in Schedule C. For the purpose of this adjuster, payment of domestic group A arrears cannot exceed the programmed amount by more than U Sh 45.0 billion.

\footnotetext{
${ }^{2}$ Debt service due is defined as pre-HIPC Initiative debt service due, but from 2003/04 onwards, this excludes HIPC Initiative debt rescheduling.

${ }^{3}$ Comprising the check float and the change in government securities and government promissory notes held by the nonbank sector. The change in government securities held by the nonbank sector will be calculated from the data provided by the Central Depository System (CDS).
} 


\begin{tabular}{|l|c|c|c|c|}
\hline \multicolumn{5}{|c|}{$\begin{array}{l}\text { Schedule C: Nonbank Financing Minus Repayment of Domestic Arrears } \\
\text { (Cumulative billions of Uganda shillings, beginning July 1 of the fiscal year) }\end{array}$} \\
\hline Quarter & Dec. 31, 2007 & Mar.. 31, 2008 & June 30, 2008 & June 30, 2009 \\
\hline $\begin{array}{l}\text { (A) Nonbank } \\
\text { financing }\end{array}$ & -13 & 28 & 31 & 150 \\
\hline $\begin{array}{l}\text { (B) Domestic arrears } \\
\text { repayment }\end{array}$ & 112 & 210 & 280 & 330 \\
\hline \begin{tabular}{l} 
(C) Total=(A)-(B) \\
\hline
\end{tabular} & -125 & -182 & -249 & -180 \\
\hline
\end{tabular}

13. The ceiling on NDA of the BOU for end-June will be adjusted upward by the daily average amount of commercial bank automatic access to the BOU discount window and rediscounting of government securities by commercial banks.

14. The ceiling on NDA of the BOU for every test date will be adjusted downward/upward to reflect decreases/increases in the legal reserve requirements on deposits in commercial banks. The adjuster will be calculated as the percent change in the reserve requirement multiplied by the actual amount of required reserves (Uganda shillings and foreign-currency denominated) at the end of the previous calendar month.

\section{G. External Borrowing Contracted or Guaranteed by the Central Government, Statutory Bodies, or the Bank of Uganda, and Arrears}

15. The assessment criterion on short-term debt refers to contracting or guaranteeing external debt with original maturity of one year or less by the government or the Bank of Uganda. Excluded from this assessment criterion are normal import-related credits. The definition of "debt" is set out in paragraph 17.

16. The program includes a ceiling on new nonconcessional borrowing with maturities greater than one year contracted or guaranteed by the government, statutory bodies, or the BOU. ${ }^{4}$ Nonconcessional borrowing is defined as loans with a grant element of less than 35 percent, calculated using average commercial interest rates references (CIRRs) published by the Organization for Economic Cooperation and Development (OECD). In assessing the level of concessionality, the 10-year average CIRRs should be used to discount loans with maturities of at least 15 years, while the 6-month average CIRRs should be used for loans with shorter maturities. To both the 10-year and 6-month averages, the following margins for differing payment periods should be added: 0.75 percent for repayment periods of less than 15 years; 1 percent for 15-19 years; 1.15 percent for 20-25

\footnotetext{
${ }^{4}$ Contraction is defined as approval by a resolution of Parliament as required in Section 20(3) of the Public Finance and Accountability Act, 2003
} 
years; and 1.25 percent for 30 years or more. The ceiling on nonconcessional external borrowing or guarantees is to be observed on a continuous basis. The coverage of borrowing includes financial leases and other instruments giving rise to external liabilities, contingent or otherwise, on nonconcessional terms. Excluded from the limits are changes in indebtedness resulting from refinancing credits and rescheduling operations, and credits extended by the IMF. For the purposes of the program, arrangements to pay over time obligations arising from judicial awards to external creditors that have not complied with the HIPC Initiative do not constitute nonconcessional external borrowing. For the purposes of the program, the Bujagali project is defined as the hydroelectric dam and related equipment located at the dam site.

17. The definition of debt, for the purposes of the limit, is set out in point 9 of the Guidelines on Performance Criteria with Respect to External Debt (Executive Board's Decision No. 12274-(00/85), August 24, 2000). It not only applies to the debt as defined in Point 9 of the Executive Board decision, but also to commitments contracted or guaranteed for which value has not been received. The definition of debt set forth in No. 9 of the Guidelines on Performance Criteria with Respect to External Debt in Fund Arrangements reads as follows:

(a) For the purpose of this guideline, the term "debt" will be understood to mean a current, i.e., not contingent, liability, created under a contractual arrangement through the provision of value in the form of assets (including currency) or services, and which requires the obligor to make one or more payments in the form of assets (including currency) or services, at some future point(s) in time; these payments will discharge the principal and/or interest liabilities incurred under the contract. Debts can take a number of forms, the primary ones being as follows: (i) loans, i.e., advances of money to the obligor by the lender made on the basis of an undertaking that the obligor will repay the funds in the future (including deposits, bonds, debentures, commercial loans and buyers' credits) and temporary exchanges of assets that are equivalent to fully collateralized loans under which the obligor is required to repay the funds, and usually pay interest, by repurchasing the collateral from the buyer in the future (such as repurchase agreements and official swap arrangements); (ii) suppliers' credits, i.e., contracts where the supplier permits the obligor to defer payments until some time after the date on which the goods are delivered or services are provided; and (iii) leases, i.e., arrangements under which property is provided which the lessee has the right to use for one or more specified period(s) of time that are usually shorter than the total expected service life of the property, while the lesser retains the title to the property. For the purpose of the guideline, the debt is the present value (at the inception of the lease) of all lease payments expected to be made during the period of the agreement excluding those payments that cover the operation, repair, or maintenance of the property. (b) Under the definition of debt set out in point 9(a) above, arrears, penalties, and judicially awarded damages 
arising from the failure to make payment under a contractual obligation that constitutes debt. Failure to make payment on an obligation that is not considered debt under this definition (e.g., payment on delivery) will not give rise to debt.

18. The ceiling on the accumulation of new external payments arrears is zero. This limit, which is to be observed on a continuous basis, applies to the change in the stock of overdue payments on debt contracted or guaranteed by the government, the BOU, and statutory bodies ${ }^{5}$ from their level at end-June 2006. It comprises those external arrears reported by the Trade and External Debt Department of the BOU, the Macro Department of the Ministry of Finance that cannot be rescheduled because they were disbursed after the Paris Club cutoff date.

\section{H. Monitoring and Reporting Requirements}

19. The authorities will inform the IMF staff in writing at least ten business days (excluding legal holidays in Uganda or in the United States) prior to making any changes in economic and financial policies that could affect the outcome of the financial program. Such policies include but are not limited to customs and tax laws (including tax rates, exemptions, allowances, and thresholds), wage policy, and financial support to public and private enterprises. The authorities will similarly inform the IMF staff of any nonconcessional external debt contracted or guaranteed by the government, the BOU, or any statutory bodies, and any accumulation of new external payments arrears on the debt contracted or guaranteed by these entities. The authorities will furnish an official communication to the IMF describing program performance of quantitative and structural assessment criteria and benchmarks within 8 weeks of a test date. The authorities will on a regular basis submit information to IMF staff with the frequency and submission time lag as indicated in Table 1. The information should be mailed electronically to AFRUGA746@IMF.ORG.

\footnotetext{
${ }^{5}$ This definition is consistent with the coverage of public sector borrowing defined by the Fund (includes the debt of the general government, monetary authorities, and entities that are public corporations which are subject to the control by government units, defined as the ability to determine general corporate policy or by at least 50 percent government ownership).
} 
Table 1. Summary of Reporting Requirements

\begin{tabular}{|c|c|c|c|}
\hline $\begin{array}{l}\text { Reporting } \\
\text { institution }\end{array}$ & Report/Table & Frequency & $\begin{array}{l}\text { Submission } \\
\quad \text { lag }\end{array}$ \\
\hline \multirow[t]{12}{*}{$\begin{array}{l}\text { I. Bank of } \\
\text { Uganda }\end{array}$} & Issuance of government securities. & Weekly & $\begin{array}{l}5 \text { working } \\
\text { days }\end{array}$ \\
\hline & Interest rates on government securities. & Weekly & $\begin{array}{l}5 \text { working } \\
\text { days }\end{array}$ \\
\hline & $\begin{array}{l}\text { Operations in the foreign exchange market and daily average } \\
\text { exchange rates. }\end{array}$ & Weekly & $\begin{array}{l}5 \text { working } \\
\text { days }\end{array}$ \\
\hline & Consumer price index. & Monthly & 2 weeks \\
\hline & $\begin{array}{l}\text { Balance sheet of the BOU, consolidated accounts of the } \\
\text { commercial banks, and monetary survey. The Internal Audit } \\
\text { Department (IAD) of the BOU will review the reconciliations } \\
\text { of monetary survey data with the financial records and the } \\
\text { audited financial statements. Any revisions to monetary } \\
\text { survey data, in line with the recommendations of the IMF } \\
\text { safeguards mission, will be documented and reconciled with } \\
\text { the previous presentation to ensure accurate reporting. }\end{array}$ & Monthly & 4 weeks \\
\hline & $\begin{array}{l}\text { Composition of foreign assets and liabilities of the BOU by } \\
\text { currency of denomination. }\end{array}$ & Monthly & 4 weeks \\
\hline & $\begin{array}{l}\text { Statement of (i) cash balances held in project accounts at } \\
\text { commercial banks; (ii) total value (measured at issue price) of } \\
\text { outstanding government securities from the Central } \\
\text { Depository System (CDS); and (iii) the stock of government } \\
\text { securities (measured at issue price) held by commercial banks } \\
\text { from the CDS. }\end{array}$ & Monthly & 6 weeks \\
\hline & $\begin{array}{l}\text { Summary of (i) monthly commodity and direction of trade } \\
\text { statistics; (ii) disbursements, principal and interest, flows of } \\
\text { debt rescheduling and debt cancellation, arrears, and } \\
\text { committed undisbursed balances - by creditor category; and } \\
\text { (iii) composition of nominal HIPC Initiative assistance, } \\
\text { disaggregated into grants, flow rescheduling, and stock-of- } \\
\text { debt reduction by creditor. }\end{array}$ & Monthly & 6 weeks \\
\hline & $\begin{array}{l}\text { Summary of stock of external debt, external arrears, and } \\
\text { committed undisbursed loan balances by creditor. }\end{array}$ & Quarterly & 6 weeks \\
\hline & $\begin{array}{l}\text { Standard off-site bank supervision indicators for deposit } \\
\text { money banks. }\end{array}$ & Quarterly & 4 weeks \\
\hline & $\begin{array}{l}\text { Summary table of preliminary program performance } \\
\text { comparing actual monthly outcome with adjusted program } \\
\text { targets for (i) base money; (ii) net claims on central } \\
\text { government by the banking system; (iii) stock of external } \\
\text { arrears; (iv) new nonconcessional external borrowing; and (v) } \\
\text { net international reserves }\end{array}$ & Quarterly & 5 weeks \\
\hline & $\begin{array}{l}\text { Daily average amount of commercial bank automatic access to } \\
\text { the BOU discount window and rediscounting of government } \\
\text { securities by commercial banks. }\end{array}$ & Quarterly & 4 weeks \\
\hline
\end{tabular}


Table 1. Summary of Reporting Requirements

\begin{tabular}{|c|c|c|c|}
\hline $\begin{array}{l}\text { Reporting } \\
\text { institution }\end{array}$ & Report/Table & Frequency & $\begin{array}{l}\text { Submission } \\
\quad \text { lag }\end{array}$ \\
\hline \multirow[t]{7}{*}{$\begin{array}{l}\text { II. Ministry of } \\
\text { Finance }\end{array}$} & $\begin{array}{l}\text { Summary of central government accounts. Revenues shall be } \\
\text { recorded on a cash basis. Expenditures shall be recorded when } \\
\text { checks are issued, except for domestic and external debt- } \\
\text { service payments, cash transfers to districts, and externally } \\
\text { funded development expenditures. Expenditures on domestic } \\
\text { interest will be recorded on an accrual basis and external debt } \\
\text { service will be recorded on a commitment basis (i.e., when } \\
\text { payment is due). Cash transfers to districts will be recorded as } \\
\text { expenditures of the central government when the transfer is } \\
\text { effected by the BOU. Expenditures on externally funded } \\
\text { development programs will be recorded as the sum of } \\
\text { estimated disbursements of project loans and grants by } \\
\text { donors, less the change in the stock of government project } \\
\text { accounts held at the BOU and domestic commercial banks. }\end{array}$ & Monthly & 6 weeks \\
\hline & $\begin{array}{l}\text { Summary of outstanding stock of group (B) domestic arrears. } \\
\text { Group (B) arrears comprise the stock of CCS/IFMS arrears } \\
\text { incurred after end-June } 2004 .\end{array}$ & Quarterly & 6 weeks \\
\hline & $\begin{array}{l}\text { Summary of contingent liabilities of the central government. } \\
\text { For the purpose of the program, contingent liabilities include } \\
\text { all borrowings by statutory bodies, government guarantees, } \\
\text { claims against the government in court cases that are pending, } \\
\text { or court awards that the government has appealed. }\end{array}$ & Quarterly & 6 weeks \\
\hline & $\begin{array}{l}\text { Detailed central government account of disbursed budget } \\
\text { support grants and loans, HIPC support, and external debt } \\
\text { service due and paid. }\end{array}$ & Monthly & 4 weeks \\
\hline & $\begin{array}{l}\text { Detailed central government account of disbursed donor } \\
\text { project support grants and loans. }\end{array}$ & Monthly & 6 weeks \\
\hline & $\begin{array}{l}\text { Statement on new loans contracted during the period } \\
\text { according to loan agreements. }\end{array}$ & Quarterly & 6 weeks \\
\hline & $\begin{array}{l}\text { Updated national accounts statistics (real and nominal) } \\
\text { according to UBOS and medium-term projections. }\end{array}$ & Quarterly & 4 weeks \\
\hline
\end{tabular}




\title{
INTERNATIONAL MONETARY FUND
}

\author{
UGANDA \\ Second Review Under the Policy Support Instrument and \\ Modifications to Assessment Criteria-Informational Annex
}

Prepared by the African Department

(In consultation with other departments)

Approved by Robert Corker and Mark Plant

November 29, 2007

- $\quad$ Relations with the Fund. Describes financial and technical assistance by the IMF and provides information on the safeguards assessment and exchange system. Outstanding Fund credit was SDR 6 million (3 percent of quota) at end-September 2007.

- $\quad$ Relations with the World Bank Group. Describes World Bank Group strategy, portfolio, and Bank-Fund collaboration.

- $\quad$ Statistical Issues. Assesses the quality of statistical data. Economic data are generally adequate for surveillance purposes, although some shortcomings remain. 


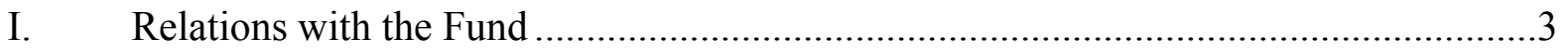

II. Relations with the World Bank Group ..........................................................

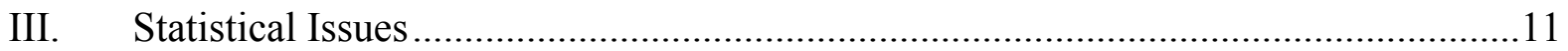




\section{APPENDIX I. UGANDA: RELATIONS WITH THE FUND}

(As of October 31, 2007)

I. Membership Status: Joined 09/27/1963; Article VIII

\section{General Resources Account: \\ Quota}

Fund holdings of currency

\section{SDR Department:}

Net cumulative allocation

Holdings

\section{Outstanding Purchases and}

Loans:

Enhanced Structural Adjustment Facility (ESAF)/Poverty Reduction and Growth

Facility (PRGF) arrangements

V. Financial Arrangements:

$\begin{array}{lcccc}\text { Type } & \begin{array}{c}\text { Approval } \\ \text { Date }\end{array} & \begin{array}{c}\text { Expiration } \\ \text { Date }\end{array} & \begin{array}{c}\text { Amount Approved } \\ \text { (SDR Million) }\end{array} & \begin{array}{c}\text { Amount Drawn } \\ \text { (SDR Million) }\end{array} \\ \text { PRGF } & 09 / 13 / 2002 & 01 / 31 / 2006 & \frac{13.50}{13.50} & 100.43 \\ \text { ESAF/PRGF } & 11 / 10 / 1997 & 03 / 31 / 2001 & 100.43 & 120.51 \\ \text { ESAF } & 09 / 06 / 1994 & 11 / 09 / 1997 & 120.51 & 219.12 \\ \text { ESAF } & 04 / 17 / 1989 & 06 / 30 / 1994 & 219.12 & \end{array}$

SDR Million
$\%$ Quota
100.0
100.0

$\%$ Allocation

100.00

1.61

$\%$ Quota

6.00

3.32

\section{Projected Payments to Fund}

(based on existing use of resources and present holdings of SDRs)

\begin{tabular}{lccccr} 
& Overdue & \multicolumn{5}{c}{ Forthcoming } \\
\cline { 2 - 6 } & $\underline{2007}$ & $\underline{2008}$ & $\underline{2009}$ & $\underline{2010}$ & $\underline{2011}$ \\
Principal & 0.00 & 0.00 & 0.00 & 0.20 & 1.00 \\
Charges/interest & $\underline{0.31}$ & $\underline{1.15}$ & $\underline{1.15}$ & $\underline{1.15}$ & $\underline{1.15}$ \\
Total & $\underline{0.31}$ & $\underline{1.15}$ & $\underline{1.15}$ & $\underline{1.35}$ & $\underline{2.15}$
\end{tabular}


VII. Implementation of HIPC Initiative:

Commitment of HIPC assistance

$\begin{array}{rr}\begin{array}{r}\text { Original } \\ \text { framework }\end{array} & \begin{array}{r}\text { Enhanced } \\ \text { framework }\end{array}\end{array}$

Decision point date

$4 / 23 / 1997 \quad 2 / 7 / 2000$

Assistance committed (1999 NPV terms) ${ }^{6}$

Total assistance (US\$ million)

347.00

656.00

Of which: Fund assistance

68.90

91.00

(US\$ million)

Completion point date

April 1998 May 2000

Delivery of Fund assistance (SDR million)

Assistance disbursed to the member

$51.51 \quad 68.10$

119.61

Interim assistance

8.20

8.20

Completion point balance

51.51

59.90

111.41

Additional disbursement of interest income ${ }^{7}$

2.06

2.06

\section{Implementation of MDRI Assistance}

I. Total Debt Relief (SDR Million) ${ }^{8}$

Of which: MDRI

HIPC
87.73

75.85

11.88

II. Debt Relief by Facility (SDR Million)

\footnotetext{
${ }^{6}$ Net present value (NPV) terms at the completion point under the original framework, and NPV terms at the decision point under the enhanced framework.

${ }^{7}$ Under the enhanced Initiative for Heavily Indebted Poor Countries (HIPC Initiative), an additional disbursement is made at the completion point corresponding to interest income earned on the amount committed at the decision point but not disbursed during the interim period.

${ }^{8}$ The Multilateral Debt Relief Initiative (MDRI) provides 100 percent debt relief to eligible member countries that are qualified for the assistance. The debt relief covers the full stock of debt owed to the Fund as of end2004 which remains outstanding at the time the member qualifies for such debt relief. The MDRI is financed by bilateral contributions and the Fund's own resources, as well as the resources already disbursed to the member under the HIPC Initiative (see Section VII above).
} 


\section{Eligible Debt}

Delivery Date

January 2006

\section{GRA}

N/A $\underline{\text { PRGF }}$

87.73 $\underline{\text { Total }}$

87.73

\section{Safeguards Assessments}

Under the Fund's safeguards policy, assessments with respect to the PSI are voluntary. An update assessment of the Bank of Uganda (BOU) was completed on April 10, 2007 and concluded that the BOU had strengthened its safeguards framework since the 2003 assessment. The main developments included implementation of International Financial Reporting Standards, publication of financial statements, establishment of an audit committee, and strengthening of the internal audit function. Staff made recommendations to address remaining vulnerabilities in the legal and internal control areas.

\section{Exchange Rate Arrangement}

The official exchange rate is determined on the interbank market for foreign exchange. As of October 31, 2007, the official exchange rate was U Sh 1,736 per U.S. dollar. The exchange system is free of restrictions on the making of payments and transfers for current international transactions. Uganda's exchange rate regime is classified as managed float without predetermined path.

\section{Article IV Consultation}

The Executive Board concluded the last Article IV consultation on December 15, 2006. The next Article IV consultation with Uganda will be held on the 24-month cycle, subject to the provisions of the decision on consultation cycles approved on July 15, 2002.

In February and April 2001, joint World Bank/Fund missions visited Kampala as part of the Financial Sector Assessment Program (FSAP). A final report was provided to the authorities in November 2001, and an MFD mission discussed the report with the authorities during the Article IV consultation discussion in November 2002, and the Financial System Stability Assessment was prepared for Board discussion in February 2003. In November 2004, a joint World Bank/Fund missions visited Kampala for a FSAP update. 


\section{Policy Support Instrument (PSI)}

Uganda initiated a 16-month PSI with the Fund in January 2006. The 16-month PSI was replaced by a new three-year PSI in December 2006.

\section{Technical Assistance}

Uganda has received extensive technical assistance from the Fund in recent years. ${ }^{9}$

An FAD mission visited Kampala in April 1998 to advise the authorities on public service pension reform issues, and another mission visited Kampala in September 1998 to assist the authorities in improving customs administration procedures. A resident advisor in the area of local government budgeting began a six-month assignment in August 1998, which was subsequently extended to October 1999. An FAD resident advisor on budgeting and commitment control commenced a six-month assignment in November 1998, which was extended until June 2002. In October 2000, an FAD mission visited Kampala to provide technical assistance in tax policy and administration. A joint Bank/Fund TA mission visited Kampala in October 2003 to help harmonize tax investment incentives among the member countries of the EAC. An FAD TA mission on tax administration also visited Uganda in October 2004 to develop a comprehensive reform plan for the Uganda Revenue Authority (URA), followed by visits in April 2005 and April - May 2006. Two FAD resident advisors (coordinated through AFRITAC-East) assisted the implementation of a CCS at the local government level and the Fiscal Decentralization Strategy between June 2004 and February 2005. In the upcoming joint FAD-WB mission, the FAD will be represented by AFRITAC East, which would follow up on the recommendations of the 2005 FAD arrears mission and check whether the new financial and physical reporting system for local governments has been implemented.

A STA multisector statistics mission visited Kampala in December 1998 to conduct a comprehensive assessment of Uganda's macroeconomic statistics, including data compilation and dissemination, and to provide recommendations for improvements. Follow-up STA missions in national accounts and money and banking statistics visited Kampala in MarchApril 2000 to examine the status of implementation of the previous recommendations. A STA mission on government financial statistics (GFS) visited Uganda in December 2001 to assist authorities in improving fiscal reporting by establishing regular reporting systems that are aligned with the GFS Manual 2001, as well as ensuring consistency within monetary sector data for the government. A follow-up mission on GFS visited Uganda in May 2003. A mission visited Uganda during February-March 2002 to review balance of payment statistics and the progress in implementing the recommendations of the multisector mission of 1998 and of the national accounts mission of 2000 with respect to the measurement of goods

\footnotetext{
${ }^{9}$ For a description of technical assistance provided prior to 1998, see the staff report for Uganda's request for a three-year arrangement under the PRGF (Country Report 02/213).
} 
imports. A follow-up mission on balance of payments statistics visited Uganda in August 2003. Uganda is participating in the General Data Dissemination System (GDDS) and its metadata were initially posted on the Fund's Dissemination Standards Bulletin Board in May 2000. A STA mission was in Uganda during February 2005 to prepare a data ROSC.

Since the 2001 FSAP, MFD's TA to Uganda has focused on liquidity management, exchange rate intervention, central bank accounting and auditing, and banking supervision. The authorities have effectively used TA advice on these topics, and they have made good use of an MFD resident advisor, who took up her initial appointment in mid-July 2001. The advisor was fully integrated into the supervision function and has been involved in all aspects of the work, including participating in on-site examinations; she has subsequently been replaced by a second resident advisor. MFD has fielded two TA missions (July 2001 and January 2002) to assist the authorities with liquidity management and address the problems of interest rate volatility and exchange rate interventions. The BOU has started implementing the recommendations made in the report, and now clearly separates sterilization operations and liquidity management; however, they are still having problems with interest rate and exchange rate volatility and have requested follow-up TA in this area. In March and September-October 2002, MFD provided TA to improve central bank accounting and the Bank of Uganda's accounting manual. A TA evaluation visit was conducted in June 2003, and an MFD mission following up on monetary and exchange rate operations, public debt, and liquidity management was conducted in March 2004. An FSAP update mission was conducted in November 2004 and focused on access, outreach, and stability issues, which also updated progress made since the last FSAP. A TA mission on enhancing the effectiveness of monetary policy implementation and developing financial markets was conducted in August 2005. Finally, a joint MCM/BOU workshop on financial market development was held in April 2006.

\section{Future Technical Assistance Priorities}

The priorities for Fund technical assistance in the next few years will be in the areas of tax administration, public expenditure management, especially control and monitoring of public arrears at both central and local government levels, monetary and exchange rate management, bank supervision, national accounts statistics, reporting standards for government finance statistics, monetary and balance of payments statistical reporting, central bank accounting, and audit and debt management.

\section{Resident Representative}

The Fund has maintained a resident representative in Uganda since July 1982. 


\section{APPENDiX II. Uganda: Relations WITH THE WORLD BANK GROUP}

(As of November 10, 2007)

\section{Partnership in Uganda's Development Strategy}

1. Uganda's development strategy is based on the revised Poverty Eradication Action Plan (PEAP) ${ }^{10}$ launched in May 2005. This medium-term national planning framework guides government policy both at sector and district levels. The PEAP aims at accelerating economic growth, reducing poverty and inequality, and improving human development. It has five pillars: (i) economic management; (ii) production, competitiveness and income; (iii) security, conflict-resolution, and disaster management; (iv) good governance; and (v) human development.

\section{Bank Group Strategy}

2. The World Bank's assistance to Uganda is set out in a Joint Assistance Strategy (UJAS) which was approved by the Bank's Board in January 2006. The strategy now guides the activities of 10 other development partners in addition to the Bank. Within it, the Bank provides substantial support to the PEAP through annual Poverty Reduction Support Credits (PRSCs). PRSC6 was approved by the World Bank's Executive Board in April 2007.

3. Another form of direct budget support is debt relief. In addition to the Heavily Indebted Poor Countries (HIPC) initiatives ${ }^{11}$, Uganda received 100 percent debt relief under the Multilateral Debt Relief Initiative (MDRI) approved by the World Bank Board on March 28,2006 . The initiative, which became effective July 01,2006 , will cancel US $\$ 2.7$ billion of Uganda's debt owed to IDA.

\section{Bank Portfolio}

4. As of September 30, 2007, Uganda's portfolio included 20 Bank-supported projects, with total net commitments of US\$1430 million.

5. For the fiscal year 2007/08, the Board has approved additional financing of US\$12.0 million to the Second Agricultural Research and Training project, and the Kampala Institutional and Infrastructure Development project(US\$34 million). Projects still in the pipeline include Local Government Management Service Delivery (US\$55 million, of which

\footnotetext{
${ }^{10}$ The PEAP, first prepared in 1997 is a dynamic document and was revised in 2000 and 2004 and preparations for the third round of revision (2008) are underway.

${ }^{11}$ Uganda reached completion point for the HIPC in April 1998 and for the Enhanced HIPC in May 2000.
} 
US\$23 million will support the Northern Uganda Peace, Recovery and Development Plan), the Second Lake Victoria Environment Management project(US\$28million), and PRSC 7. In the fiscal year 2006/07, PRSC6 (US\$125 million), Power Sector Development project (US\$300 million), and the Private Power Generation (Bujagali) project (US\$115 million) ${ }^{12}$ were approved.

\section{Bank-Fund Collaboration in Specific Areas}

6. Specific areas for collaboration include:

- Poverty reduction strategy paper - The staffs of the two institutions prepare joint assessments of the PRSP and progress reports. The Joint Staff Advisory Note on the Poverty Status Report was presented to the two boards in June 2007.

- Debt sustainability analysis - The staffs of the two institutions have worked with the authorities to update the Uganda DSA, last updated in November 2006

- Public expenditure management - Through the 2005 public expenditure review (PER), the World Bank helped to prepare an action plan for public expenditure and financial accountability which is monitored annually by a Government-chaired working group. The Bank's public expenditure reviews have now moved "upstream" to consider fiscal space, the strategic allocation of resources across sectors, and the efficiency of sector spending. The 2007 PER, which analyzed efficiency in the education sector, was delivered to government in June 2007. The 2008 PER will focus on the health sector.

- Public Financial Management - The staffs of the Fund and the Bank fielded a joint staff mission to assess budget reporting and review the functioning of the Integrated Financial Management Information System (IFMIS).

- Financial sector reform - The Bank and Fund completed a Financial Sector Assessment Program update in March 2005. In addition under the Country Economic Memorandum, the Bank carried out a thorough assessment of priorities to facilitate growth and deepening in Uganda's financial sector. Capacity-building work to support implementation on this work is closely coordinated with the Fund's PSI.

\footnotetext{
${ }^{12}$ The US\$115 million from IDA is in form of a partial risk guarantee for syndicated commercial loan, but supplements other funding from the World Bank group for this project of US\$130 million from IFC, and a MIGA guarantee of US\$115 million for the sponsor's equity.
} 
- Trade reforms and regionalization - Both the Bank and Fund are involved in the dialogue on trade reforms and regional integration, particularly in the context of the East African Community (EAC). In 2006, the Bank completed a diagnostic trade integrated study (DTIS) under the Integrated Framework (IF) for Trade Development in LDCs. Through the IF process, the Bank is supporting government in the implementation of the DTIS. As part of continued support to the EAC secretariat, the Bank completed a report "Options for strengthening EAC's Trade Integration" through consolidating the $\mathrm{CU}$; (ii) developing a common trade policy; and (iii) rationalizing overlapping commitments.

Questions may be referred to Rachel K. Sebudde, Economist, Tel. (256) 414-302201. 


\section{APPENDIX III. Uganda: STATISTICAL IsSUES}

Overall, data provision is adequate for surveillance purposes, although some shortcomings remain. Uganda participates in the General Data Dissemination System (GDDS) and its metadata were initially posted on the Fund's Dissemination Standards Bulletin Board in May 2000. Partial updates of real and external sector metadata were completed in August 2005. Uganda is participating in the SDDS, government finance, and the monetary and financial statistics modules of the Fund's GDDS Project for Anglophone Africa (funded by the U.K. Department for International Development (DFID)). This project aims to assist participating countries to implement plans for improvement identified in the metadata.

In February 2005 a STA mission prepared a data ROSC, with results published in July 2006. The ROSC mission assessed data compilation and dissemination practices against international standards in national accounts, prices, government finance, and balance of payments statistics; the monetary and financial statistics were not assessed. In April 2007 a mission conducted a Special Data Dissemination Standard (SDDS) assessment focusing on dissemination practices vis-à-vis the SDDS requirements for coverage, periodicity and timeliness.

\section{Real sector statistics}

Since 2004 Uganda has been receiving technical assistance from East AFRITAC on the compilation of quarterly national accounts and training through short missions and a regional workshop. Recently, compilers have developed estimates of quarterly value added at constant 2002 prices using the International Standard Industrial Classification (ISIC) Rev III groups. However, methodological shortcomings remain relating to benchmarking. The Uganda Bureau of Statistics (UBOS) collects output data from a sample of manufacturing business establishments in the industrial belt of the country to compile a Major and a Main Index of Industrial Production (IIP). Labor market indicators such as employment, unemployment, and wages/earnings are infrequently compiled and disseminated. UBOS aims to compile and disseminate these data categories on an annual basis, but due to resource and data unavailability, these data are compiled with a two year lag. UBOS collects prices of consumer goods and services from six urban centers for computing inflation rates disseminated on the last working day of every month. According to UBOS, there are plans to expand the coverage to include another urban center. UBOS collects producer prices (factory gate prices) from a sample of manufacturing establishments located in different parts of the country, which undertake manufacturing activities as classified by ISIC. The price information is used to compute the Producer Price Index for Manufacturing (PPI-M). 


\section{Government finance statistics}

The Ministry of Finance, Planning and Economic Development (MoFPED) compiles the fiscal statistics on general government including budgetary central government and local governments but excluding extra budgetary institutions and the National Social Security Fund. A revised chart of accounts was implemented for use by all budgetary central government and local government units from July 1, 2003. Uganda reported Government Finance Statistics (GFS) data according to the GFSM 2001 framework for the 2004 GFS Yearbook, but further submissions are still pending. External debt for the public sector, external debt guaranteed by the public sector, and debt service schedule data are disseminated in millions of dollars and in Uganda shillings (using end of year exchange rates) for the fiscal year (July to June).

\section{Monetary and financial statistics}

In February 2006, a monetary and financial statistics mission found that the monetary statistics are basically sound from the point of view of data integrity and timeliness. However, there are a number of areas where improvements are needed to align the data with the recommendations of the Monetary and Financial Statistics Manual (MFSM). The detailed balance sheet of the Bank of Uganda (BOU) is well designed for producing the analytical data; however, (1) reverse repos between the BOU and the other depository corporations (ODCs) are not classified as advances to banks, (2) there is some inconsistency among departments in the BOU in determining which foreign assets are in reserve assets; (3) loans and advances are presented net of provisions for loans losses; (4) the proper classification of many positions of the Development Finance Department is difficult because the main classification used in the accounts is the original source of funds, rather than the unit subject to a claim or liability; and (5) the economic and accounting nature of administered and internally managed funds of the BOU is unclear.

Currently, the coverage of the depository corporations survey (DCS) includes the BOU and 18 ODCs, three of which are under liquidation. The DCS does not include seven credit institutions and four microfinance institutions, that also accept deposits. However, their data are collected on a monthly basis and published in the BOU's quarterly and annual economic reports. The mission recommended that the depository corporations sector be defined to include these deposit-taking financial institutions, and that their deposits be included in the monetary aggregates.

A monetary and financial statistics mission planned for March 2008 will review the progress in improving procedures used by the BOU in the compilation of monetary data and will assist the authorities in moving to adopt the standardized report forms. 


\section{External sector statistics}

The 2005 data ROSC mission found that the balance of payments statistics broadly follow the fifth edition of the Balance of Payments Manual (BPM5), but that there are some departures from recommended definitions, scope, and classifications. The mission urged completion of the conversion to the BPM5 and the development of new source data and estimation techniques in the following areas: exports of freight and imports of passenger transportation, compensation of employees, direct investment abroad, portfolio investment and financial derivatives. International trade data could be improved by incorporation of results from the Survey of Informal Cross-Border Trade and greater use of trade partner country data sources.

Balance of payments data are compiled and disseminated for calendar and fiscal years in the BOU's publications Quarterly Economic Report and Annual Report, as well as the UBOS annual Statistical Abstract. Data cover the entire economy and include all operations between residents and nonresidents. Quarterly balance of payments data are disseminated in an analytical format or on the basis of standard components, in accordance with the requirements of the IMF Balance of Payments Manual, Fifth Edition (BPM5).

The BOU has requested technical assistance to determine better ways in which trade data can be compiled. The BOU is also seeking technical assistance to determine how best to capture securities trading and deposits from off-shore agents into the balance of payments. 
14
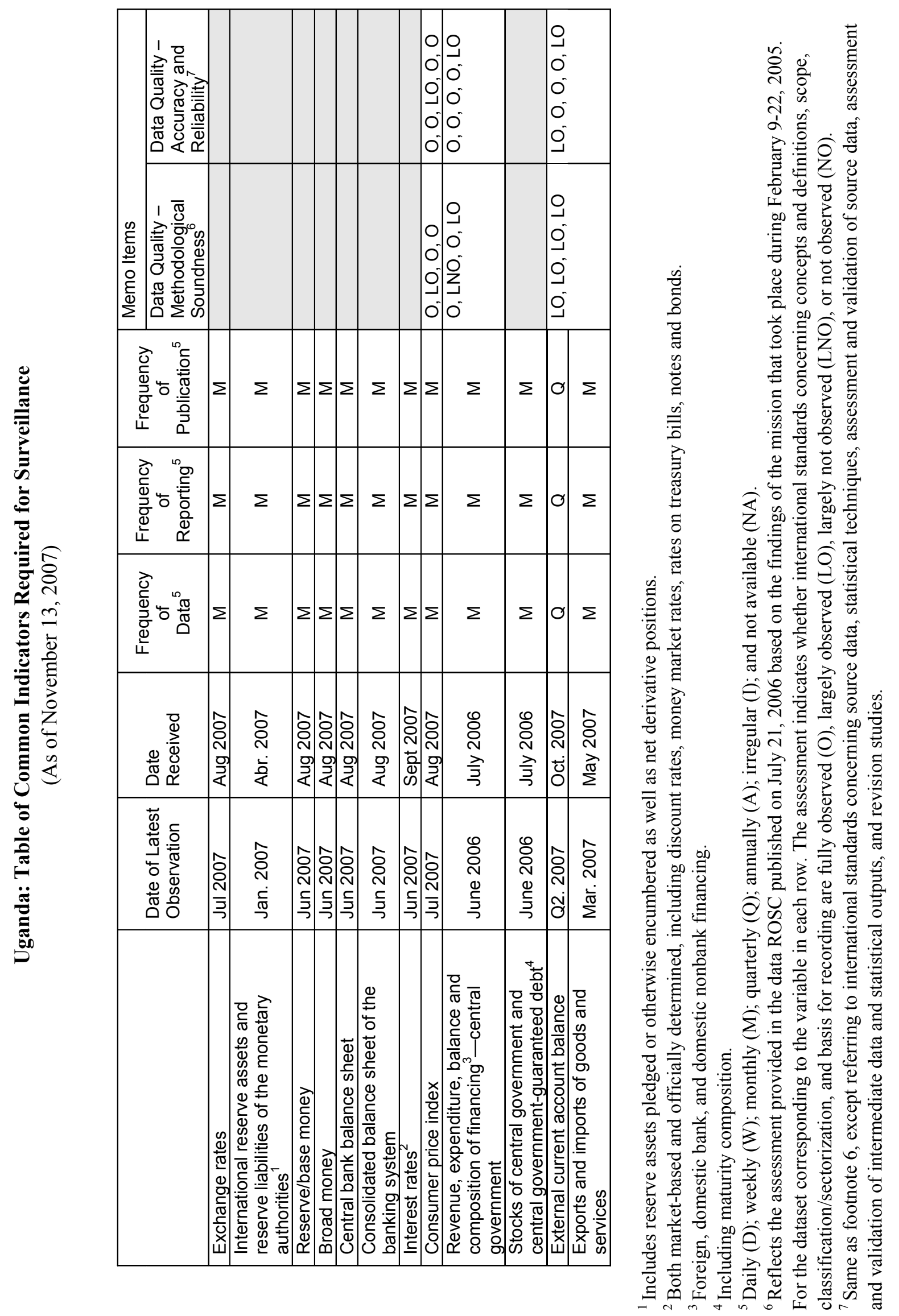


\title{
INTERNATIONAL MONETARY FUND AND \\ INTERNATIONAL DEVELOPMENT ASSOCIATION
}

UGANDA

\section{Joint IMF/World Bank Debt Sustainability Analysis ${ }^{13}$}

Prepared by the Staffs of the International Monetary Fund and the International Development Association

Approved by Robert Corker and Mark Plant (IMF)

and Sudhir Shetty and Brian Pinto (IDA)

November 30, 2007

\begin{abstract}
Based on the joint Low-Income Country Debt Sustainability Framework of the World Bank and the IMF, Uganda is assessed to be at low risk of debt distress. Its debt ratios have improved substantially over the past few years (thanks to HIPC and MDRI debt relief) and are projected to do so over the medium term and beyond under the baseline scenario. Having achieved debt sustainability, the authorities plan to address infrastructure constraints aiming at reaching high economic growth. The Joint DSA assesses the challenges and trade-offs of increasing public investment while maintaining debt sustainability.
\end{abstract}

1. Uganda has achieved debt sustainability by implementing sound macroeconomic policies and receiving debt relief. The HIPC and MDRI debt relief have improved Uganda's debt sustainability outlook substantially by leading to a drastic reduction in Uganda's debt burden indicators. ${ }^{14}$ As a result, external debt was US $\$ 1.5$ billion (13 percent of GDP) at end-2006/07, compared with US\$4.5 billion (47 percent of GDP) a year earlier. Consequently, all debt burden indicators are currently below their policy-dependent

\footnotetext{
${ }^{13}$ Prepared by the IMF and World Bank staff. DSA assumptions and results have been discussed thoroughly with the authorities. All debt indicators refer to Uganda's fiscal year (July-June).

${ }^{14}$ Total MDRI relief (including future interest) delivered in 2005/06 and 2006/07 approached US\$3.6 billion.
} 
thresholds. ${ }^{15}$ The debt service-to-exports ratio, the key indicator of short-term external liquidity, fell from 15.3 percent in 2004/05 to 6.5 percent in 2006/07.

2. With lack of infrastructure being one of the key constraints to growth, the authorities plan to increase spending on infrastructure. Infrastructure development (in transportation, electricity, and water) has been given priority in the 2007/08 budget and in the medium term. The authorities plan to build the Bujagali hydroelectric plant to help ease power constraints. The project is being financed by a private consortium with participation from multilateral lenders. However, as of mid-November, the terms, conditions and guarantees for financing had not been finalized. The construction of one more hydroelectric plant, possibly at Karuma, and of infrastructure necessary for the development of the oil sector (such as a small refinery and pipelines) are still at the planning stage.

\section{The baseline DSA assesses the implications of the authorities' plans to increase} spending on infrastructure. The baseline DSA assumes that the government would contract or guarantee debt on non-concessional terms up to US $\$ 400$ million, with annual average disbursements of $3 / 4$ percent of GDP. ${ }^{16}$ The baseline scenario therefore shows the impact of partial public financing on non-concessional terms of the investment in infrastructure. In addition, the DSA assumes that multilateral and bilateral official debt would be contracted on concessional terms. However, the baseline DSA excludes a number of factors that are difficult to assess and quantify at this stage, specifically: (i) the construction of the Karuma hydroelectric plant; (ii) the investment in infrastructure in the oil sector; (iii) and oil production (expected to commence in 2009), as the scale of production is yet to be determined. Box 1 summarizes the key assumptions of the baseline DSA.

\footnotetext{
${ }^{15}$ The World Bank's Country Policy and Institutional Assessment (CPIA) ranks Uganda as a "strong performer." Debt burden thresholds for strong performers are NPV of debt to GDP ratio of 50 percent, NPV of debt-to-exports ratio of 200 percent, NPV of debt-to-revenue ratio of 300 percent, debt-service-to-exports ratio of 25 percent, and debt-service-to-revenue ratio of 35 percent.

${ }^{16}$ The investment in the Bujagali project is expected to reach US\$800 million. Plans call for the investment to be financed through equity participation in, and loans to the private consortium. The government intends to negotiate favorable financing terms in the event it ends up financing a portion of the project.
} 


\section{Box 1. Key Assumptions Underlying the Baseline DSA}

Under the baseline scenario, construction of the Bujagali hydroelectric plant begins in $2007 / 08$ and will be completed by $2009 / 10$.

Reflecting the higher investment in infrastructure and the subsequent increase in production, real GDP growth would average 7 percent between 2007/08 and 2012/13, before slowing to 6 percent by $2019 / 20$.

Exports of goods are projected to grow $11 \frac{1}{2}$ percent on average between 2007/08 and $2026 / 27$, driven largely by an increase in the export volume of non-traditional exports.

The current account deficit would be above its historical norm of 5 percent of GDP by $2 \frac{1}{2}$ percentage points on average between 2007/08 and 2012/13 (peaking at 9 $1 / 2$ percent of GDP in 2008/09) on account of higher imports related to the construction of the Bujagali plant. Ongoing adjustment of the economy (reflected in a growing share of non-traditional exports) would help the current account deficit stabilize at 6 percent of GDP in the outer years. These trends would imply a gradual improvement in the current account deficit excluding official transfers from $81 / 2$ percent of GDP in 2006/07 to 7 percent of GDP in 2026/27.

Fiscal revenues are assumed to increase gradually from $13 \frac{1}{2}$ percent of GDP in $2006 / 07$ to $163 / 4$ percent of GDP in 2012/13. With grants declining below 3 percentage points of GDP in the medium term, non-interest expenditures are projected to decline slightly to about 19 percent of GDP, consistent with a primary balance close to zero in the outer years.

Official external loans are projected to amount to US\$485 million per year on average throughout the medium term, and US $\$ 420$ million per year in the outer years. The DSA assumes that IDA will support Uganda with lending operations throughout the projection period.

Compared with the 2006 DSA, the current baseline scenario assumes higher real GDP growth, higher imports (particularly over the next three years, owing to imports for the construction of the Bujagali plant), and higher exports (reflecting the recent good performance and improved prospects for the sector). Export projections in particular are driven by WEO forecasts of stronger growth of Uganda's partner country demand for non-oil imports, expected to average 81/2 percent in real terms over 2007-13 and assumed to grow at the same rate up to 2027 . These projections allow for small gains in export market shares over the medium term, and assume that the strong export performance over the past four years will not be reversed. On balance, the new assumptions result in a somewhat better current account. The current baseline scenario also includes an upward revision of the MDRI relief granted to Uganda (which now includes relief of US $\$ 486$ million from the AfDF not included in the 2006 DSA) and a downward revision to expected external loans in line with the authorities' projections. The fiscal assumptions remain broadly unchanged. 


\section{EXTERnal Debt Sustainability AnAlysis}

(a) Baseline scenario

4. The external debt dynamics during the next 20 years would be favorable (Tables 1, 1a, and 1b, and Figure 1). All three debt-burden indicators are expected to remain well below their policy-dependent thresholds throughout the period. Reflecting the borrowing for spending on infrastructure, the NPV of debt-to-GDP ratio is expected to rise from 5.9 percent in 2006/07 to 9.9 percent in 2012/13, but decline to 6.9 percent by 2026/27. The NPV of debt-to-exports is expected to peak at 61.4 percent in 2009/10 and decline substantially thereafter. The debt service-to-exports ratio is expected to continue along a downward trend, reflecting the delivery of HIPC and MDRI assistance.

Table 1. Uganda: Indicative External Debt Burden Indicators, 2006/07-2026/27

(Percent)

\begin{tabular}{|c|c|c|c|c|c|c|}
\hline & \multirow{2}{*}{$\begin{array}{l}\text { Indicative } \\
\text { Thresholds }^{1} \\
\end{array}$} & \multicolumn{5}{|c|}{ Uganda } \\
\hline & & $2006 / 07$ & $2009 / 10$ & $2012 / 13$ & $2016 / 17$ & $2026 / 27$ \\
\hline \multicolumn{7}{|l|}{ NPV of debt-to-GDP ratio } \\
\hline Baseline scenario & 50 & 5.9 & 10.0 & 9.9 & 9.5 & 6.9 \\
\hline High investment scenario & 50 & 5.9 & 13.9 & 13.8 & 11.5 & 7.4 \\
\hline \multicolumn{7}{|l|}{ NPV of debt-to-exports ratio } \\
\hline Baseline scenario & 200 & 37.8 & 61.4 & 48.8 & 43.7 & 27.1 \\
\hline High investment scenario & 200 & 37.8 & 85.2 & 69.8 & 53.0 & 29.4 \\
\hline \multicolumn{7}{|l|}{ Debt-service-to-exports ratio } \\
\hline Baseline scenario & 25 & 6.5 & 4.1 & 3.2 & 2.0 & 1.7 \\
\hline High investment scenario & 25 & 6.5 & 7.5 & 7.5 & 5.0 & 2.7 \\
\hline
\end{tabular}

Source: Staff projections and calculations.

${ }^{1}$ Policy dependent thresholds for a strong performer according to the World Bank's CPIA.

(b) Standardized sensitivity analysis

5. The baseline scenario points to low risk of debt distress. Under all the standardized stress tests (see Table $1 \mathrm{~b}$ and Figure 1), the debt-to-GDP, debt-to-exports, and debt service-to-exports indicators remain below their threshold values throughout the next 20 years.

6. However, a large macroeconomic shock could worsen Uganda's NPV of debt-toexports ratio significantly. A combined shock (by one-half standard deviation) to growth, 
exports, GDP deflator, and non-debt creating flows in 2007/08-2008/09, would raise Uganda's NPV of debt-to-exports ratio to 152.8 percent in 2008/09. Such a shock would have a significant impact on debt sustainability by putting the Ugandan economy at a high indebtedness level for a prolonged period. Uganda's NPV of the debt-to-GDP and debtservice ratios would nonetheless remain well below the policy-dependent thresholds.

\section{(c) Customized sensitivity analysis-High investment scenario}

\section{An alternative scenario has been developed to reflect even higher public} investment in infrastructure. In addition to the investment envisaged in the baseline scenario, the alternative scenario includes investment in Karuma and the oil sector (a total of US\$422 million during 2007/08-2010/11), and in other infrastructure projects (US\$1.5 billion during the first decade, and US\$2 billion during the subsequent decade). Public financing for these investments is assumed to be through a blend of concessional (one quarter) and nonconcessional (three quarters) loans.

\section{Under this scenario, debt ratios will remain within their policy dependent} thresholds (Figure 2). Under all but one of the standardized stress tests, the NPV of debt-toGDP and debt-to-exports as well as the debt service-to-exports ratio remain well below their threshold values throughout the next 20 years. However, under the combined shock to growth, exports, GDP deflator, and non-debt creating flows (most extreme stress test), the NPV of debt-to-exports threshold is breached in 2008/09-2010/11. This result is sensitive to the share of non-concessional borrowing in total borrowing (75 percent). The smaller this share is the lower are Uganda's debt indicators, including under the combined stress tests. Uganda could therefore become vulnerable to debt distress should it rely excessively on nonconcessional borrowing.

\section{Fiscal Debt Sustainability Analysis}

9. The fiscal DSA is based on the assumption of continued fiscal consolidation, though initially at a more moderate pace due to the power crisis, and on a gradual tapering off of grant inflows. Specifically, it is assumed that emergency budget spending on the energy crisis will amount to about 2 percent of GDP cumulatively in the next two years, and that grants will continue to decline from 6.3 percent of GDP in FY 2006/07, before stabilizing at below 3 percent of GDP in the medium term. Domestic revenues are projected to increase gradually to some $16 \frac{1}{2}$ percent of GDP in 2012/13, in line with the authorities'

policy objective. After a spike related to the energy crisis, non-interest expenditures will decline moderately as a percent of GDP, but then will increase again to about 19 percent of GDP, in line with projected improvement in domestic revenue collection, with primary balance close to zero.

10. Under the baseline scenario, the NPV of public debt is projected to increase gradually after a sharp decline resulting from MDRI (Tables 2a, 2b, and Figure 3). It will 
peak at about 19 percent of GDP in four years, and then decline gradually. Debt-service indicators remain manageable, with debt-service not exceeding 10 percent of revenues.

11. Uganda's public debt will remain sustainable in case of shocks. Even under the extreme stress test, the NPV of public debt will not exceed 30 percent of GDP over the projection period. Similarly, the stress tests do not indicate any debt-servicing problem.

\section{CONCLUSION}

12. The DSA analysis shows that Uganda's public debt remains sustainable under the baseline scenario. Uganda's public debt has been reduced significantly as a result of the MDRI, and with a prudent borrowing strategy and the continuation of the stability-oriented fiscal policy, debt should remain comfortably low during the projection period. While the alternative scenario shows that Uganda can adopt a higher investment program, caution on borrowing is warranted and reliance on concessional financing remains essential. 


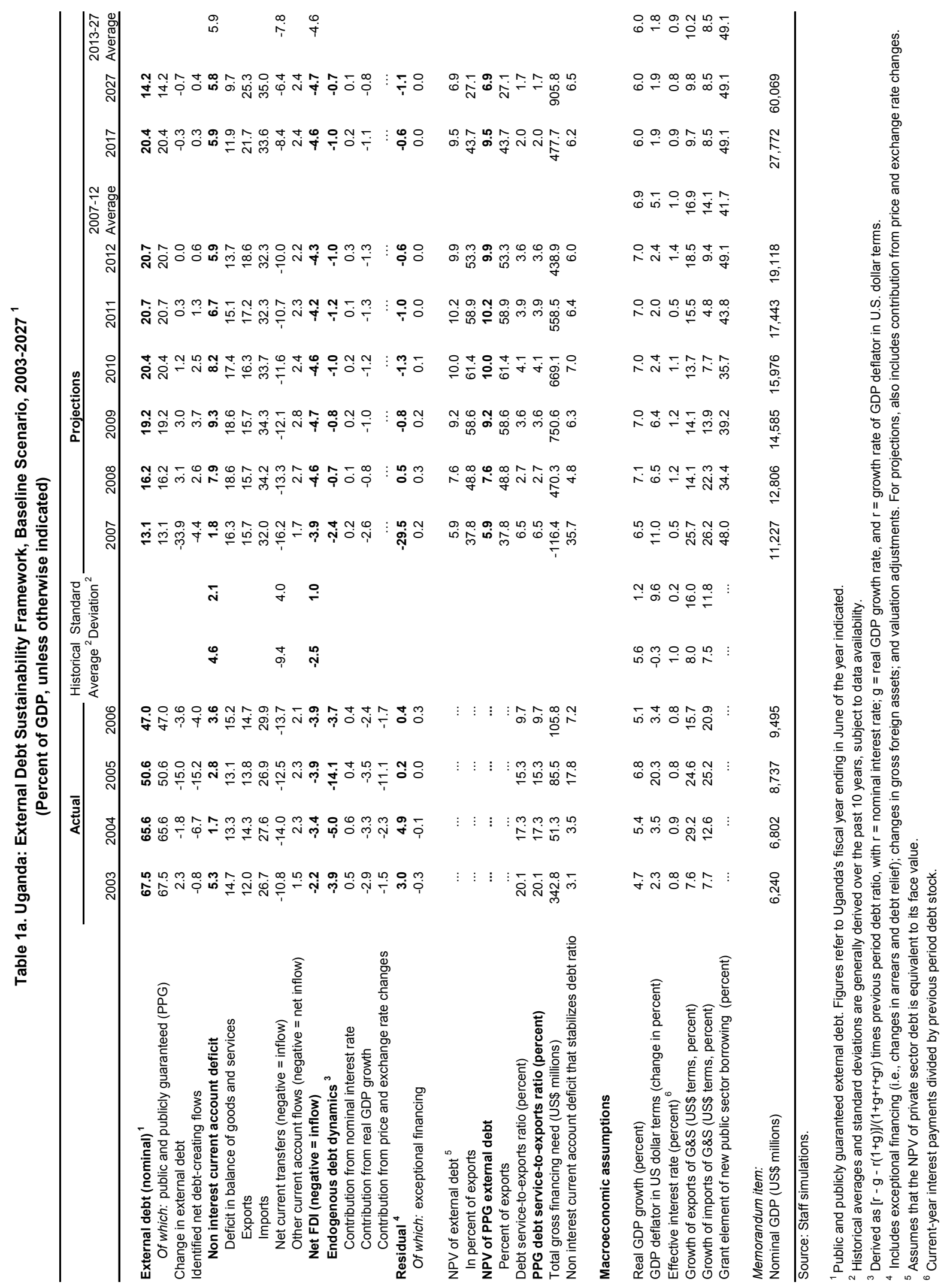


Table 1b. Uganda: Sensitivity Analyses for Key Indicators of Public and Publicly Guaranteed External Debt, 2007-2027 ${ }^{1}$ (Percent)

\begin{tabular}{|c|c|c|c|c|c|c|c|c|}
\hline & \multicolumn{8}{|c|}{ Projections } \\
\hline & 2007 & 2008 & 2009 & 2010 & 2011 & 2012 & 2017 & 2027 \\
\hline \multicolumn{9}{|c|}{ NPV of debt-to-GDP ratio } \\
\hline Baseline & 5.9 & 7.6 & 9.2 & 10.0 & 10.2 & 9.9 & 9.5 & 6.9 \\
\hline \multicolumn{9}{|l|}{ A. Alternative Scenarios } \\
\hline A1. Key variables at their historical averages in $2008-27^{2}$ & 5.9 & 7.5 & 8.3 & 8.7 & 8.9 & 9.2 & 11.8 & 14.0 \\
\hline A2. New public sector loans on less favorable terms in $2008-27^{3}$ & 5.9 & 5.0 & 7.9 & 11.6 & 13.4 & 14.4 & 17.7 & 17.9 \\
\hline \multicolumn{9}{|l|}{ B. Bound Tests } \\
\hline B1. Real GDP growth at historical average minus one standard deviation in 2008-09 & 5.9 & 7.8 & 9.7 & 10.5 & 10.7 & 10.4 & 10.0 & 7.2 \\
\hline B2. Export value growth at historical average minus one standard deviation in $2008-09^{4}$ & 5.9 & 9.2 & 13.4 & 14.0 & 14.0 & 13.6 & 12.4 & 7.9 \\
\hline B3. US dollar GDP deflator at historical average minus one standard deviation in 2008-09 & 5.9 & 9.0 & 12.8 & 14.0 & 14.2 & 13.8 & 13.3 & 9.6 \\
\hline B4. Net non-debt creating flows at historical average minus one standard deviation in $2008-09^{5}$ & 5.9 & 13.2 & 19.3 & 19.6 & 19.3 & 18.7 & 16.3 & 9.2 \\
\hline B5. Combination of B1-B4 using one-half standard deviation shocks & 5.9 & 13.9 & 24.1 & 24.5 & 24.2 & 23.4 & 20.5 & 11.8 \\
\hline B6. One-time 30 percent nominal depreciation relative to the baseline in $2008^{6}$ & 5.9 & 10.6 & 12.8 & 13.9 & 14.1 & 13.8 & 13.2 & 9.6 \\
\hline \multicolumn{9}{|c|}{ NPV of debt-to-exports ratio } \\
\hline Baseline & 37.8 & 48.8 & 58.6 & 61.4 & 58.9 & 53.3 & 43.7 & 27.1 \\
\hline \multicolumn{9}{|l|}{ A. Alternative Scenarios } \\
\hline A1. Key variables at their historical averages in $2008-27^{2}$ & 37.8 & 47.8 & 52.9 & 53.6 & 51.8 & 49.3 & 54.1 & 55.4 \\
\hline A2. New public sector loans on less favorable terms in $2008-27^{3}$ & 37.8 & 31.8 & 50.5 & 71.2 & 77.9 & 77.5 & 81.4 & 71.0 \\
\hline \multicolumn{9}{|l|}{ B. Bound Tests } \\
\hline B1. Real GDP growth at historical average minus one standard deviation in 2008-09 & 37.8 & 48.8 & 58.6 & 61.4 & 58.9 & 53.3 & 43.7 & 27.1 \\
\hline B2. Export value growth at historical average minus one standard deviation in $2008-09^{4}$ & 37.8 & 72.8 & 131.6 & 132.5 & 124.9 & 112.1 & 87.6 & 47.9 \\
\hline B3. US \$ GDP deflator at historical average minus one standard deviation in 2008-09 & 37.8 & 48.8 & 58.6 & 61.4 & 58.9 & 53.3 & 43.7 & 27.1 \\
\hline B4. Net non-debt-creating flows at historical average minus one standard deviation in $2008-09^{5}$ & 37.8 & 84.6 & 123.2 & 120.6 & 112.3 & 100.2 & 75.0 & 36.5 \\
\hline B5. Combination of B1-B4 using one-half standard deviation shocks & 37.8 & 88.3 & 152.8 & 150.1 & 139.9 & 125.0 & 94.1 & 46.5 \\
\hline B6. One-time 30 percent nominal depreciation relative to the baseline in $2008^{6}$ & 37.8 & 48.8 & 58.6 & 61.4 & 58.9 & 53.3 & 43.7 & 27.1 \\
\hline
\end{tabular}

Debt service ratio

Baseline

A. Alternative Scenarios

A1. Key variables at their historical averages in $2008-27^{2}$

A2. New public sector loans on less favorable terms in $2008-27^{3}$

$\begin{array}{llllllll}6.5 & 2.7 & 3.6 & 4.1 & 3.9 & 3.6 & \mathbf{2 . 0} & 1.7 \\ & & & & & & & \\ 6.5 & 2.9 & 4.2 & 4.7 & 4.6 & 4.4 & \mathbf{2 . 3} & 2.9 \\ 6.5 & 2.4 & 3.6 & 2.6 & 1.8 & 1.6 & \mathbf{1 . 2} & 0.4\end{array}$

B. Bound Tests

B1. Real GDP growth at historical average minus one standard deviation in 2008-09

B2. Export value growth at historical average minus one standard deviation in 2008-09

B3. US\$ GDP deflator at historical average minus one standard deviation in 2008-09

B4. Net non-debt-creating flows at historical average minus one standard deviation in 2008-09 ${ }^{5}$

B5. Combination of B1-B4 using one-half standard deviation shocks

B6. One-time 30 percent nominal depreciation relative to the baseline in $2008^{6}$

$\begin{array}{llllllll}6.5 & 2.7 & 3.6 & 4.1 & 3.9 & 3.6 & \mathbf{2 . 0} & 1.7 \\ 6.5 & 3.3 & 5.9 & 6.9 & 6.6 & 6.0 & \mathbf{4 . 6} & 3.2 \\ 6.5 & 2.7 & 3.6 & 4.1 & 3.9 & 3.6 & \mathbf{2 . 0} & 1.7 \\ 6.5 & 2.7 & 4.2 & 5.1 & 4.8 & 4.4 & \mathbf{4 . 4} & 2.6 \\ 6.5 & 3.0 & 5.3 & 6.5 & 6.1 & 5.6 & \mathbf{5 . 4} & 3.3 \\ 6.5 & 2.7 & 3.6 & 4.1 & 3.9 & 3.6 & \mathbf{2 . 0} & 1.7 \\ & & & & & & & \\ 49.0 & 49.0 & 49.0 & 49.0 & 49.0 & 49.0 & \mathbf{4 9 . 0} & 49.0\end{array}$

Memorandum item:

Grant element assumed on residual financing (i.e., financing required above baseline) ${ }^{7}$

Source: Staff projections and simulations.

'Figures refer to Uganda's fiscal year ending in June of the year indicated.

${ }^{2}$ Variables include real GDP growth, growth of GDP deflator (in U.S. dollar terms), non-interest current account in percent of GDP, and non-debt creating flows.

${ }^{3}$ Assumes that the interest rate on new borrowing is by 2 percentage points higher than in the baseline., while grace and maturity periods are the same as in the baseline.

${ }^{4}$ Exports values are assumed to remain permanently at the lower level, but the current account as a share of GDP is assumed to return to its baseline level after the shock (implicitly assuming an offsetting adjustment in import levels).

${ }^{5}$ Includes official and private transfers and FDI.

${ }^{6}$ Depreciation is defined as percentage decline in dollar/local currency rate, such that it never exceeds 100 percent.

${ }^{7}$ Applies to all stress scenarios except for A2 (less favorable financing) in which the terms on all new financing are as specified in footnote 3 . 


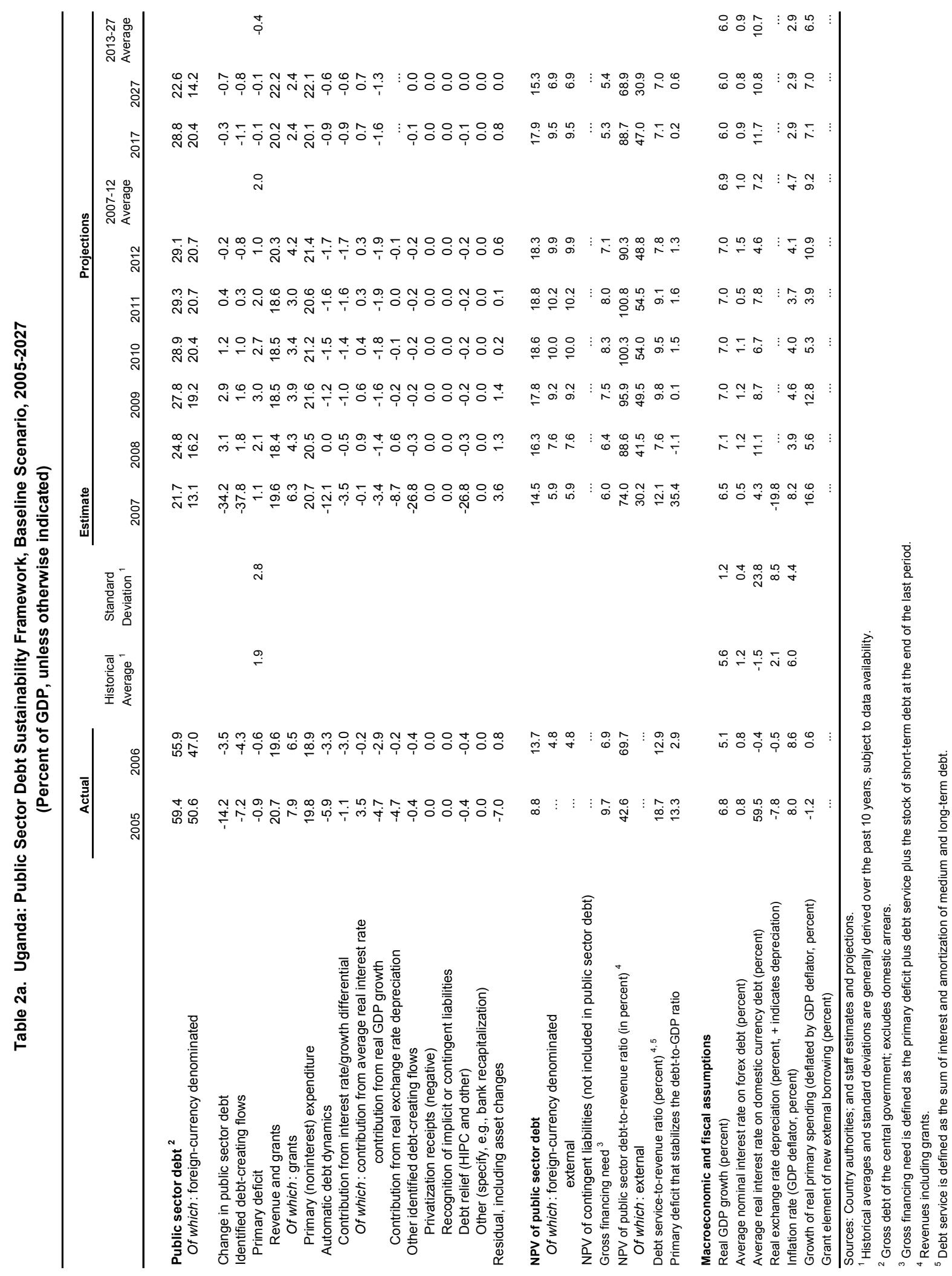


Table 2b. Uganda: Sensitivity Analysis for Key Indicators of Public Debt, 2007-2027

NPV of Debt-to-GDP Ratio
Baseline
A. Alternative scenarios
A1. Real GDP growth and primary balance are at historical averages
A2. Primary balance is unchanged from 2007
A3. Permanently lower GDP growth ${ }^{1}$
B. Bound tests
B1. Real GDP growth is at historical average minus one standard deviations in 2008-2009
B2. Primary balance is at historical average minus one standard deviations in 2008-2009
B3. Combination of B1-B2 using one-half standard deviation shocks
B4. One-time 30 percent real depreciation in 2008
B5. 10 percent of GDP increase in other debt-creating flows in 2008

Projections

$\begin{array}{llllllll}2007 & 2008 & 2009 & 2010 & 2011 & 2012 & 2017 & 2027\end{array}$

Baseline

$\begin{array}{llllllll}15 & 16 & 18 & 19 & 19 & 18 & 18 & 15 \\ & & & & & & & \\ 16 & 20 & 20 & 20 & 20 & 20 & 30 & 39 \\ 16 & 20 & 20 & 20 & 20 & 20 & 29 & 36 \\ 16 & 19 & 20 & 21 & 21 & 22 & 21 & 24\end{array}$

NPV of Debt-to-Revenue Ratio ${ }^{2}$

Baseline

\section{NPV of Debt-to-Revenue Ratio}

A. Alternative scenarios

A1. Real GDP growth and primary balance are at historical averages

A2. Primary balance is unchanged from 2007

A3. Permanently lower GDP growth

\section{B. Bound tests}

B1. Real GDP growth is at historical average minus one standard deviations in 2008-2009 B2. Primary balance is at historical average minus one standard deviations in 2008-2009

B3. Combination of B1-B2 using one-half standard deviation shocks

B4. One-time 30 percent real depreciation in 2008

B5. 10 percent of GDP increase in other debt-creating flows in 2008

Debt Service-to-Revenue Ratio ${ }^{2}$

Baseline

$\begin{array}{llllllll}16 & 20 & 22 & 24 & 24 & 26 & 26 & 29 \\ 16 & 22 & 25 & 25 & 25 & 26 & 22 & 18 \\ 16 & 22 & 23 & 24 & 23 & 24 & 20 & 17 \\ 16 & 22 & 22 & 22 & 21 & 22 & 18 & 16 \\ 16 & 29 & 29 & 30 & 29 & 28 & 25 & 19\end{array}$

A. Alternative scenarios

A1. Real GDP growth and primary balance are at historical averages

A2. Primary balance is unchanged from 2007

A3. Permanently lower GDP growth ${ }^{1}$

$\begin{array}{llllllll}85 & 92 & 108 & 111 & 112 & 110 & 98 & 76\end{array}$

\section{B. Bound tests}

B1. Real GDP growth is at historical average minus one standard deviations in 2008-2009

B2. Primary balance is at historical average minus one standard deviations in 2008-2009

B3. Combination of B1-B2 using one-half standard deviation shocks

B4. One-time 30 percent real depreciation in 2008

B5. 10 percent of GDP increase in other debt-creating flows in 2008

Sources: Country authorities; and staff estimates and projections.

${ }^{1}$ Assumes that real GDP growth is at baseline minus one standard deviation divided by the square root of 20 (i.e., the length of the projection period).

${ }^{2}$ Revenues are defined inclusive of grants. 
Figure 1. Uganda: Indicators of Public and Publicly Guaranteed External Debt Baseline Scenario

(Percent)
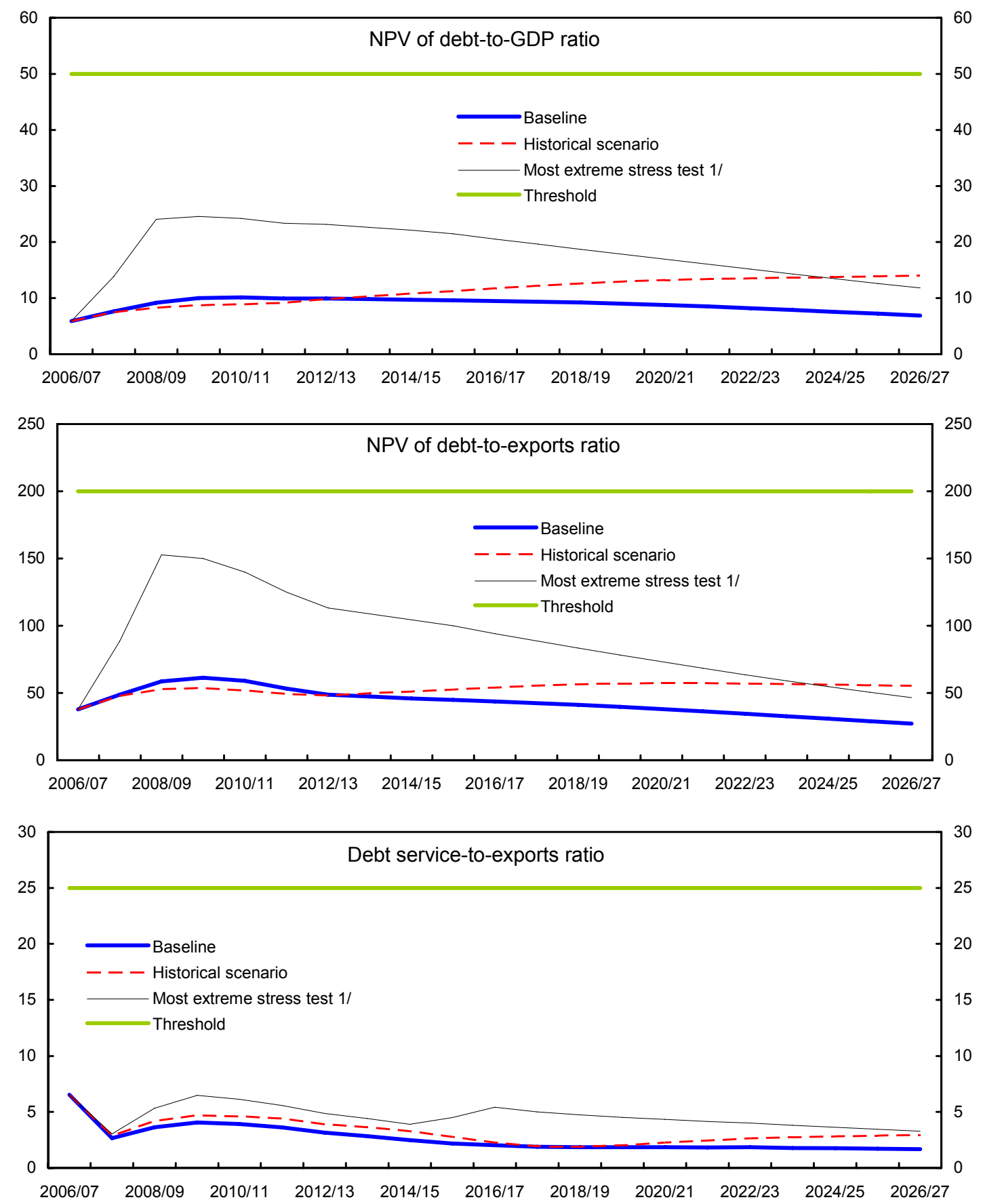

Source: Staff projections and simulations.

1/ Combination of historical averages of real GDP growth, export value growth, US\$ GDP deflator, and net non-debt-creating flows, using one-half standard deviation shocks. 
Figure 2. Uganda: Indicators of Public and Publicly Guaranteed External Debt High Investment Scenario

(Percent)
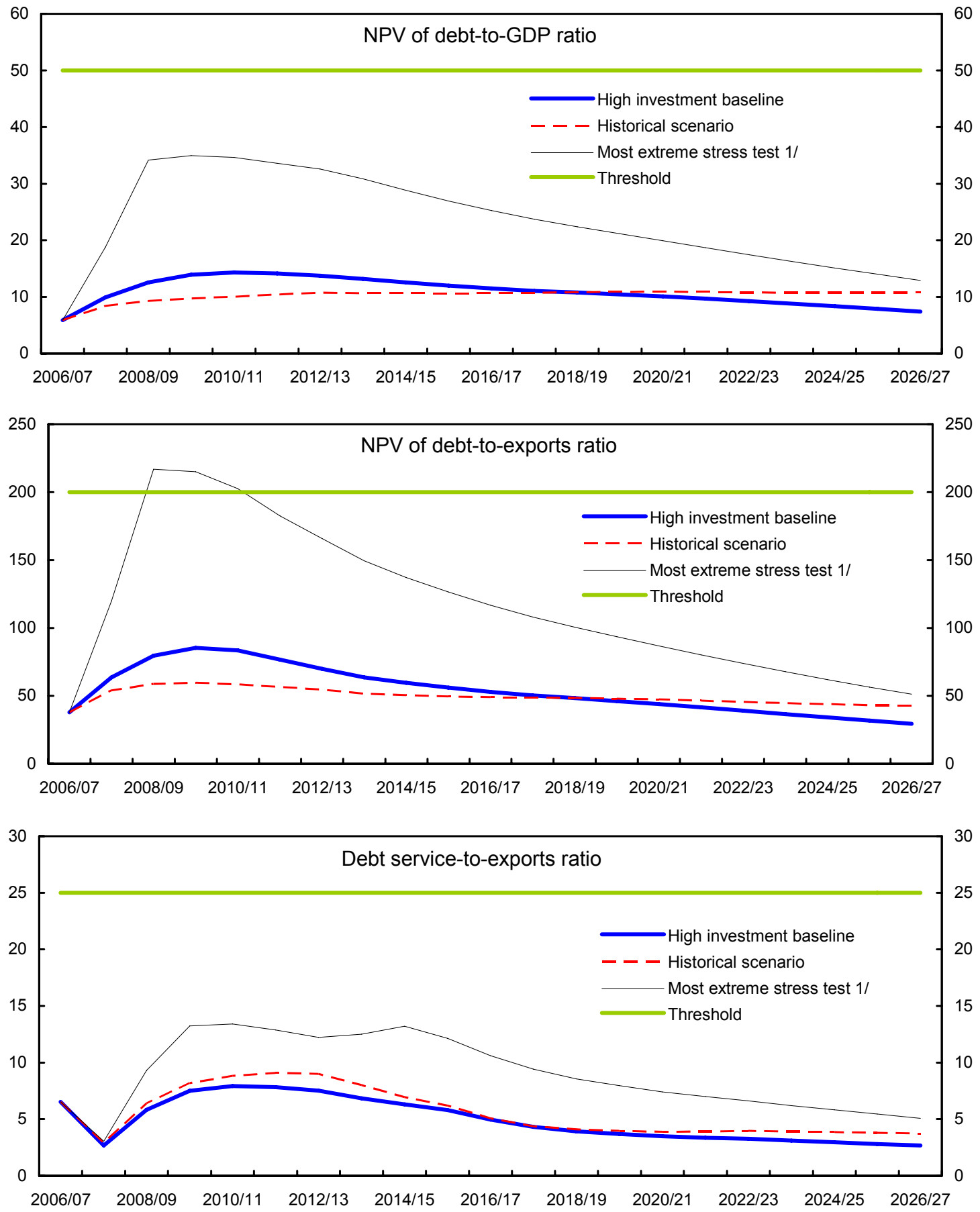

Source: Staff projections and simulations.

1/ Combination of historical averages of real GDP growth, export value growth, US\$ GDP deflator, and net non-debt-creating flows, using one-half standard deviation shocks. 
Figure 3. Uganda: Indicators of Public Debt Under Alternative Scenarios, 2007-2027
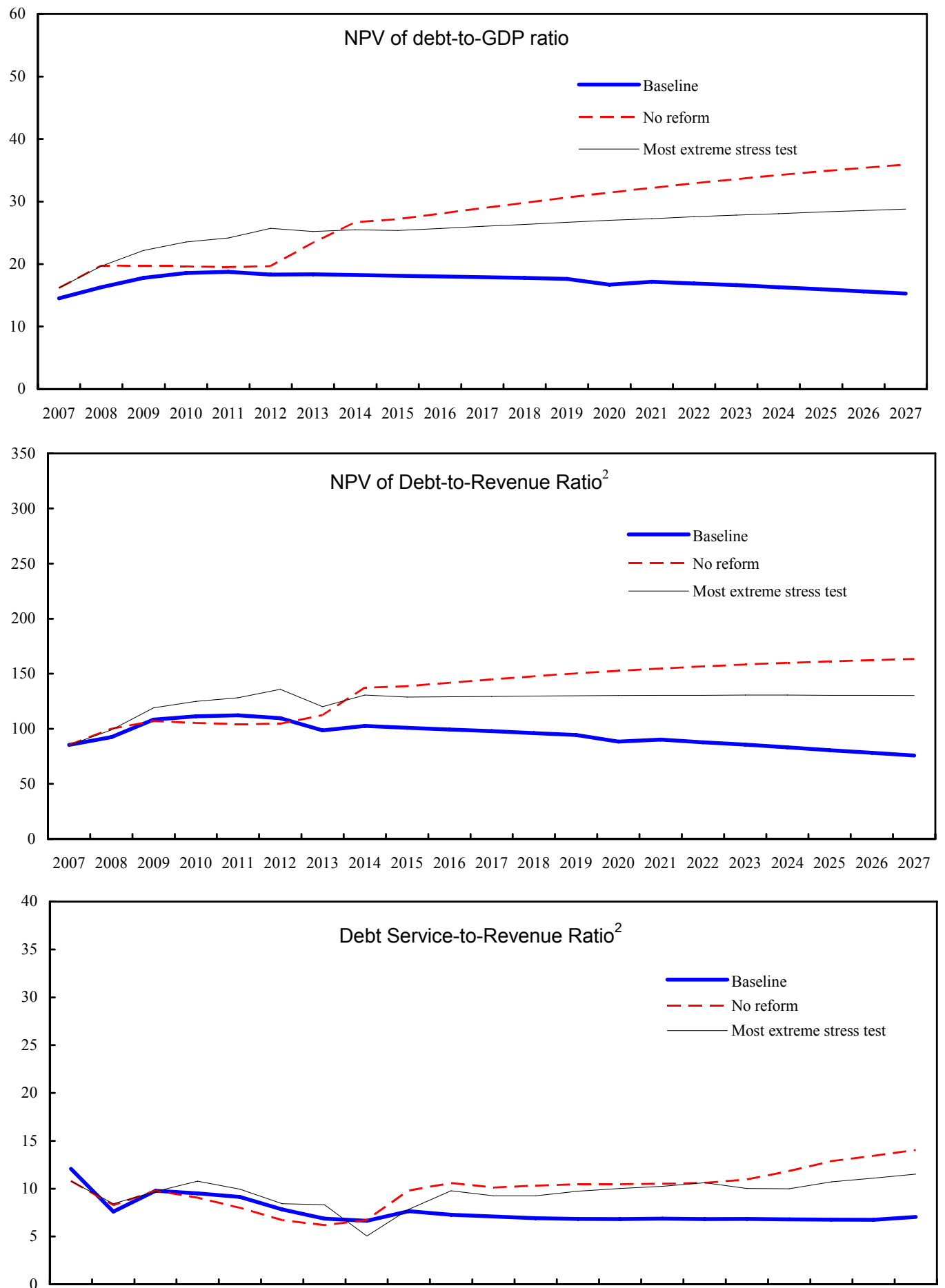

200720082009201020112012201320142015201620172018201920202021202220232024202520262027

Source: Staff projections and simulations.

${ }^{1}$ Most extreme stress test is the test that yields the highest ratio in 2017.

${ }^{2}$ Revenue including grants. 


\section{IMF Executive Board Completes Second Review Under Policy Support Instrument (PSI) for Uganda}

The Executive Board of the International Monetary Fund (IMF) today completed the second review under a three-year Policy Support Instrument (PSI) for Uganda. The PSI was approved on December 15, 2006 (see Press Release No. 06/281). The program objectives included macroeconomic stability, debt sustainability, financial sector deepening, and improved public sector financial management.

The Executive Board also approved Uganda's request for waiver for the non-observance of the end-June 2007 quantitative assessment criterion on the ceiling on the increase in base money liabilities of the Bank of Uganda as well as for the subsequent modification of quantitative assessment criteria designed to limit such occurrences in the future.

The IMF's framework for PSIs is designed for low-income countries that may not need IMF financial assistance, but still seek close cooperation with the IMF in preparation and endorsement of their policy frameworks. PSI-supported programs are based on countryowned poverty reduction strategies adopted in a participatory process involving civil society and development partners. This is intended to ensure that PSI-supported programs are consistent with a comprehensive framework for macroeconomic, structural and social policies to foster growth and reduce poverty. Members' performance under a PSI is reviewed semi-annually, irrespective of the status of the program (see Public Information Notice No. $\underline{05 / 145})$.

Following the Executive Board's discussion, Mr. Takatoshi Kato, Deputy managing Director and Acting Chair, stated:

"Uganda's economy has continued to perform strongly, owing to appropriate fiscal and monetary policies and the country's structural reform efforts. A positive economic outlook, however, hinges on addressing key infrastructure bottlenecks, financial sector development, and maintaining sound economic policies in the face of volatile foreign exchange flows and budgetary pressures. 
"A continued focus on price stability as the primary objective of monetary policy has allowed inflation to ease after temporary supply shocks last year. This focus will remain essential as increased volatility in foreign exchange flows poses challenges to the conduct of monetary policy.

"The government's restraint on less-essential current expenditure and continued efforts in tax revenue collection will be vital to raise public saving, provide room for poverty-reducing spending, and avoid domestic arrears. Expenditures associated with the Commonwealth Heads of Government Meeting in Kampala, floods, and peace in the North have already led to some expenditure overruns this fiscal year, and left limited space to accommodate additional budgetary pressures.

"A strong focus on public investment is needed to eliminate infrastructure bottlenecks and increase productivity. Implementation delays in donor-financed projects have led the government to explore alternative approaches to infrastructure investment and financing. Projects should be evaluated carefully in terms of their cost effectiveness and impact on debt sustainability, especially to the extent that financing may be non-concessional.

"Transparency and an appropriate balance between spending and saving will be key elements to maximize Uganda's benefits from future oil production. The government's comprehensive approach to the management of oil resources and the plans to introduce a national energy policy are encouraging steps toward these objectives," Mr. Kato said. 


\section{Statement by Peter Gakunu, Executive Director for Uganda and Godwill Efiong Ukpong, Senior Advisor to the Executive Director December 19, 2007}

1. The Ugandan authorities express appreciation to the Executive Board, Management and staff for valuable engagement and support for their macroeconomic and structural reform program under the PSI. They welcome the concise, informative and balanced set of staff reports on economic developments, challenges and outlook in Uganda. They are in broad agreement with the thrust of the analyses, conclusions, and recommendations.

\section{Recent Macroeconomic Developments and Performance}

2. Competent macroeconomic management and appropriate response to emerging economic problems, including acute electricity supply bottlenecks, have facilitated the achievement of better-than-expected economic performance. Some key indicators of strong economic performance include: robust real GDP growth of 6.2 percent in 2006/07, compared to 5.1 percent in 2005/06; and successful containment of underlying inflation expected to fall below the targeted ceiling of 5 percent in 2007/08. Progress in addressing electricity shortages and the associated boosting of economic activity, and favorable international commodity prices, contributed to observed GDP growth. The recent inflationary pressure arose mainly from the one-time shock of increases in electricity tariffs and temporary sugar and diesel fuel shortages.

3. The authorities' prudent public finance management, aimed at minimizing costs, enhancing savings, and debt sustainability, has largely underpinned past and current economic achievements. The Bank of Uganda (BOU) complemented the prudent fiscal stance by skillfully managing the surge in foreign exchange inflows since late 2006 by taking suitable monetary policy measures to arrest the resultant appreciation of the shilling.

4. Notwithstanding the attainment of some important policy objectives, the Ugandan authorities are aware that a number of challenges to further economic progress require continuous implementation of strong policies and reforms. Mobilizing long-term savings for investment and financing of infrastructure critical for sustainable economic growth and poverty reduction; improving the business environment to enhance the role of private sector in the economy; facilitating financial deepening; and strengthening human capacity for better service delivery are some of the major challenges going forward. Other challenges include meeting the expected high cost of September 2007 floods in eastern and northern parts of the country, and articulating suitable monetary policy measures to deal with continuous foreign exchange inflows. In this regard, the authorities have taken necessary actions to address the 
challenges, including alleviation of electricity shortage through addition of new generating capacity and providing for additional investment in infrastructure in the 2007/08 budget. Other actions taken in this respect include a near doubling of funds for clearing domestic arrears in 2008 in order to sustain the country's low debt profile, and continuation with the implementation of sound economic reform policies.

\section{Performance Under the PSI}

5. The authorities' unwavering commitment to sustaining macroeconomic stability and advancing structural reforms is demonstrated by the observance of all end-June 2007 assessment criteria, except the ceiling on base money where there was a temporary deviation from the target. However, this was subsequently met at end-September 2007. The expansion of the monetary base was associated with policy measures adopted by the BOU to stem appreciation of the shilling following strong foreign exchange inflows and rising sterilization costs. The Ugandan Revenue Authority (URA) has made commendable progress under the PSI; its revenue collection exceeded initial program projections by 0.3 percent of GDP, and contributed significantly to meeting the end-June 2007 assessment criterion on credit to government. Effective policy implementation by the BOU has facilitated soundness of the banking system and stability of the exchange rate. The Bank has introduced Net Domestic Assets (NDA of the BOU) as the near-term operating target to accord it greater flexibility in dealing with temporary currency flows or unanticipated shifts in money demand, while preparing for eventual adoption of inflation targeting by enhancing data collection, analysis and outreach. The authorities' implementation of structural measures as envisaged, has been instrumental to the achievement of policy objectives under the program.

\section{Macroeconomic Policies for 2007/08 and the MTEF}

6. In addition to the traditional areas of policy objectives, namely maintenance of macroeconomic stability, stimulation of sustainable growth, and reduction of poverty, the authorities have increased budget allocations for investments in infrastructure, energy, education, rural development, and arrears repayment. Investments in these sectors, along with the reported positive macroeconomic outlook, are expected to boost GDP growth in the near to medium-term and facilitate increased role of the private sector in the economy. Real GDP growth is projected at 7 percent over the next few years, while inflation is projected at below 5 percent by end-2007/08. Imports for Bujagali dam construction are however, expected to widen the current account deficit, but without undermining external sustainability. The authorities see the risk of increased oil prices as manageable, especially as commercial oil production is due to commence in 2009 , with derivable oil revenue to be incorporated into the MTEF. The planned national energy policy aims at transparency, fiscal sustainability, and appropriate balance between current spending and savings for the future. These developments should help mitigate the risk going forward. 
7. The authorities are aware of and take seriously other downside risks to the favorable economic prospects, including electricity and infrastructure bottlenecks, especially delays in the construction of the Bujagali dam, and the likelihood of an overshoot in CHOGM-related expenditure jeopardizing priority spending. The government made substantial budget allocations for financing the supply of essential growth-enhancing infrastructure, while most CHOGM-related expenditures were for revamping infrastructure such as roads and the airport expected to support productive economic activities and wealth creation overtime. The temporary extension of a limited government loan to the Bujagali project is aimed at minimizing delays and associated costs of its construction, while the commencement of domestic oil production in 2009 is expected to enhance government revenue profile and assist in meeting outstanding financial obligations. The authorities consider that the risks can be effectively managed.

\section{Fiscal Policy and Public Sector Reforms}

8. In line with the MTEF, the Ugandan authorities are committed to prudent public expenditure management. Accordingly, the 2007-08 budget is anchored on a strategy of targeted increases in domestic revenue collection and sustained expenditure control, with improvement in domestic revenue targeted at 0.7 percentage point to 14.1 percent of GDP. The budget also provides for reduction in the deficit, excluding grants. The authorities consider these targets feasible, given the better-than-expected tax revenue performance in the last quarter of 2006/07 and the first quarter of 2007/08; tight control over non-priority spending; and ongoing efforts to improve tax administration. The government's announced tax holidays for exporters, involving revenue loss of 0.1 percent of GDP and inline with East African Community practice, is seen as manageable and exceptional. In order to address spending pressures, largely associated with the recent hosting of CHOGM and emergency spending on floods and peace in the north without incurring new arrears, the government is focusing on reallocation within the budget envelope. In line with Fund advice, steps taken to address domestic arrears include introduction of integrated personnel and payroll system, and verification of gratuity and pension arrears for FY 2006/07.

9. The authorities' new Debt Management Strategy will, among other things, support the selection and financing of turnkey projects being considered to speed up investment in productivity-enhancing infrastructure deemed viable by the Bank-Fund DSA. Projects will be evaluated on a case-by-case basis for cost effectiveness and impact on debt sustainability. The strategy provides for borrowing for priority sectors on concessional terms. The Debt Management Strategy will guide domestic and external borrowing and repayment of arrears.

\section{Monetary and Financial Sector Policies}

10. The monetary authority is committed to implementing policies that would bring underlying inflation to under 5 percent by end 2007/08. The BOU is making use of a mix of 
instruments to help achieve the inflation objective, while carrying out sterilization necessary to contain the likely effects of rapid capital inflows on the exchange rate. Ugandan banks are well-capitalized and profitable, and provide more credit to the private sector. However, access to financial services, particularly in rural areas, is limited due to high costs and shallowness of the financial sector. The government and the BOU are preparing a comprehensive financial sector development strategy aimed at financial deepening and facilitation of credit for productive economic activities in all parts of the country.

\section{Other Structural Reforms}

11. The government is committed to making further progress on structural reforms. A policy paper on new regulatory framework for non-bank financial institution is under preparation for submission and consideration by the Cabinet. The authorities are pursuing governance reforms and improvements in public procurement.

\section{Conclusion}

12. The Ugandan authorities have been steadfast in their commitment to effective and successful implementation of sound macroeconomic and structural reform policies under the PSI. All end-June 2007 assessment criteria, except the ceiling on base money for which a waiver is being requested, have been met. The government's budget strategy is anchored on expenditure restraint and increased revenue mobilization in line with the MTEF designed to help advance growth and development. The authorities' new Debt Management Strategy is serving as a guide to domestic and external borrowing to ensure debt sustainability to which the authorities are committed. The authorities call on the international community, including the Fund, to continue with support for the country's effort to deal with outstanding challenges to economic development. They, therefore, request for a waiver of the missed assessment criterion and approval for completion of the second review of performance under the PSI. 